\title{
Reactivity of dolomitizing fluids and Mg source evaluation of fault-controlled dolomitization at the Benicàssim outcrop analogue (Maestrat Basin, E Spain)
}

\author{
E. Gomez-Rivas ${ }^{\text {a,b,f }}$, M. Corbellab,f, J.D. Martín-Martín ${ }^{\text {,d,f, }}$, S.L. Stafford ${ }^{\text {e,f }}$, A. Teixell ${ }^{\text {b,f }}$, \\ P.D. Bons ${ }^{\text {a }}$, A. Griera ${ }^{b}$ and E. Cardellach ${ }^{b}$ \\ ${ }^{a}$ Department of Geosciences, Eberhard Karls University Tübingen, Wilhelmstr. 56, 72074 Tübingen, Germany \\ ${ }^{b}$ Departament de Geologia, Universitat Autònoma de Barcelona, 08193 Bellaterra (Barcelona), Spain \\ ${ }^{c}$ Departament de Petrologia, Geoquímica i Prospecció Geològica, Universitat de Barcelona, 08028 Barcelona, Spain \\ ${ }^{d}$ Group of Dynamics of the Lithosphere, Institute of Earth Sciences "Jaume Almera” (CSIC), 08028 Barcelona, Spain \\ ${ }^{e}$ ExxonMobil Upstream Research Company, P.O. Box 2189, Houston, TX 77252-2189, USA \\ ${ }^{f}$ ExxonMobil $(F C)^{2}$ Alliance - Fundamental Controls on Flow in Carbonates, USA \\ *Corresponding author. Tel: +49 707129 73147; Fax: +49 7071 293060; E-mail: enrique.gomez-rivas@uni-tuebingen.de
}

Published in Marine and Petroleum Geology (2014), 55, 26-42, doi: 10.1016/j.marpetgeo.2013.12.015

This is an author's post-print version of the manuscript. You can access the copy-edited version at: http://authors.elsevier.com/sd/article/S0264817213003218

\begin{abstract}
The mechanisms responsible for the formation of huge volumes of dolomitized rocks associated with faults are not well understood. We present a case study for high-temperature dolomitization of an Early Cretaceous (Aptian-Albian) ramp in Benicàssim (Maestrat basin, E Spain). In this area, seismic-scale fault-controlled stratabound dolostone bodies extend over several kilometres away from large-scale faults. This work aims at evaluating different $\mathrm{Mg}$ sources for dolomitization, estimating the reactivity of dolomitizing fluids at variable temperature and quantifying the required versus available fluid volumes to account for the Benicàssim dolostones. Field relationships, stable ${ }^{13} \mathrm{C}$ and ${ }^{18} \mathrm{O}$ isotopes, as well as radiogenic ${ }^{87} \mathrm{Sr} /{ }^{86} \mathrm{Sr}$ isotopes, indicate that dolomitization at Benicàssim was produced by a high temperature fluid $\left(>80^{\circ} \mathrm{C}\right) .{ }^{13} \mathrm{C}$ and ${ }^{18} \mathrm{O}$ isotopic compositions for dolomite vary from +0.5 and $+2.9 \%$ V-PDB and from +21.1 and $+24.3 \mathrm{~V}$-SMOW, respectively. A Mg source analysis reveals that the most likely dolomitizing fluid was seawater-derived brine that interacted with underlying Triassic red beds and Paleozoic basement. Geochemical models suggest that evolved seawater can be considerably more reactive than high-salinity brines, and that the maximum reactivity occurs at about $100^{\circ} \mathrm{C}$. Mass-balance calculations indicate that interstitial fluids with high pressure and/or high temperature relative to the normal geothermal gradient cannot account for the volume of dolomite at Benicàssim. Instead a pervasive fluid circulation mechanism, like thermal convection, is required to provide a sufficient volume of dolomitizing fluid, which most likely occurred during the Late Cretaceous post-rift stage of the Maestrat Basin. This study illustrates the importance of fluid budget quantification to critically evaluate genetic models for dolomitization and other diagenetic processes.
\end{abstract}

Keywords: hydrothermal dolomitization; stratabound dolostone; Mg source; fluid reactivity; Maestrat Basin; carbonate reservoir quality.

\section{Introduction}

More than half of the Earth's carbonate rocks are dolomitized (Zenger et al., 1980; Land, 1985; Warren, 2000; Machel, 2004), and some $60 \%$ of worldwide oil and $40 \%$ of gas reserves are stored in carbonate reservoirs (Montaron, 2008). Dolomitization is one of the most important diagenetic processes that modify the petrophysical properties of carbonates (porosity and permeability), thus controlling fluid flow and oil recovery (e.g. 
Allan and Wiggins, 1993; Warren, 2000). A dolostone unit can be a reservoir, but it can also act as a barrier to flow (e.g. Lucia, 2004) depending on the original properties of the host rock, the pre- and post-dolomitization diagenetic history, the reservoir geometry and the type of dolomitization. Predicting the distribution of reservoir and non-reservoir rocks in dolomitized fields using subsurface data is a difficult task, because replacement dolomitization and associated processes (dolomite cementation and calcitization/dedolomitization) cause complex diagenetic overprints. In fact, dolomitized reservoirs are typically multiple-porosity systems (Purser et al., 1994). The vast majority of dolostones $\left(\mathrm{CaMg}\left[\mathrm{CO}_{3}\right]_{2}\right)$ are of secondary origin, so that they formed by replacement of calcite $\left(\mathrm{CaCO}_{3}\right)$ in different tectonic and geochemical settings as a consequence of the interaction of host limestone or lime sediments with fluids that caused the dolomitizing reaction (e.g. Warren, 2000; Machel, 2004; Whitaker et al., 2004; Roure et al., 2005). A common type of reservoir is the one composed of structurally controlled hydrothermal dolomite (HTD; Davies and Smith, 2006). Such dolostone forms by hydrothermal fluids that are usually transported along faults and/or fractures. The term hydrothermal refers to situations in which the advected fluid is at least $5^{\circ} \mathrm{C}$ warmer than the reacting host rock (White, 1957). Sedimentary-exhalative and Mississippi Valley-type (MVT) Pb-Zn ore deposits are commonly associated with hydrothermal dolomite (e.g. Cathles and Smith, 1983; Anderson and Garven, 1987; Shelton et al. 1992; Corbella et al. 2004; Greg, 2004).

The occurrence and distribution of burial fault-controlled dolostone is mainly constrained by (a) diagenetic/hydrothermal processes that dissolve/precipitate minerals and enhance/decrease porosity, (b) limestone matrix permeability defined by the sedimentary facies and pre-dolomitization diagenesis, and (c) fault network properties (e.g. fault length, hydraulic aperture, connectivity and segmentation) which often determine fluid flow patterns. With these limitations, the resultant geometry and distribution of hydrothermal dolostones is very variable and ranges between massive irregular patches close to fault zones to stratabound bodies that extend away from faults, which act as feeding points for fluids (e.g. Davies and Smith, 2006; Wilson et al., 2007; Gasparrini et al., 2006). The principal parameters and processes controlling the transition between both end-members are still not well understood.

The composition and sources of dolomitizing fluids, as well as their driving forces, remain controversial (Braithwaite et al, 2004). Moreover, the main parameters that control dolomite stoichiometry and cation order are complex and still under debate (Dawans and Swart, 1988; Kaczmarek and Sibley, 2007; 2012). An effective replacement of calcite by dolomite requires one or more Mg sources and a physical mechanism capable of transporting sufficient amounts of it to the reaction site (Whitaker, 2004; Carmichael et al., 2008). Historically, dolomitization studies have been based on the stratigraphic, petrographic and geochemical characterization of dolostones (for reviews see Hardie, 1987; Warren, 2000; Machel, 2004), where the final outcome is normally a conceptual model illustrated by schematic cartoons. However, mass-balance calculations and numerical analyses are essential to test whether conceptual models are plausible from a hydrodynamic and hydrochemical point of view. Dolomitization models must also be hydrologic models (Machel, 2004, Whitaker et al., 2004) because realistic fluid-flow mechanisms are required to account for solute transport to and from the reaction zone. Required vs. available fluid budget quantifications must be an essential step in order to account for the fluid origin ( $\mathrm{Mg}$ sources) and transport mechanisms (driving forces) in dolomitization case studies. Certain dolomitizing fluid properties (e.g. composition, temperature) are often calculated from geochemical analysis of rock samples. However, there are scarce examples of volume 
and source quantifications in dolomitization studies (e.g. Land, 1985; Kaufman, 1994; Reinhold, 1998). With the existing numerical tools it is possible to quantify the geologic processes responsible for dolomitization and gain a better understanding of them (e.g. Corbella et al., 2006; Whitaker and Xiao, 2010; Al-Helal et al., 2012;Xiao et al., 2013; Corbella et al., 2014).

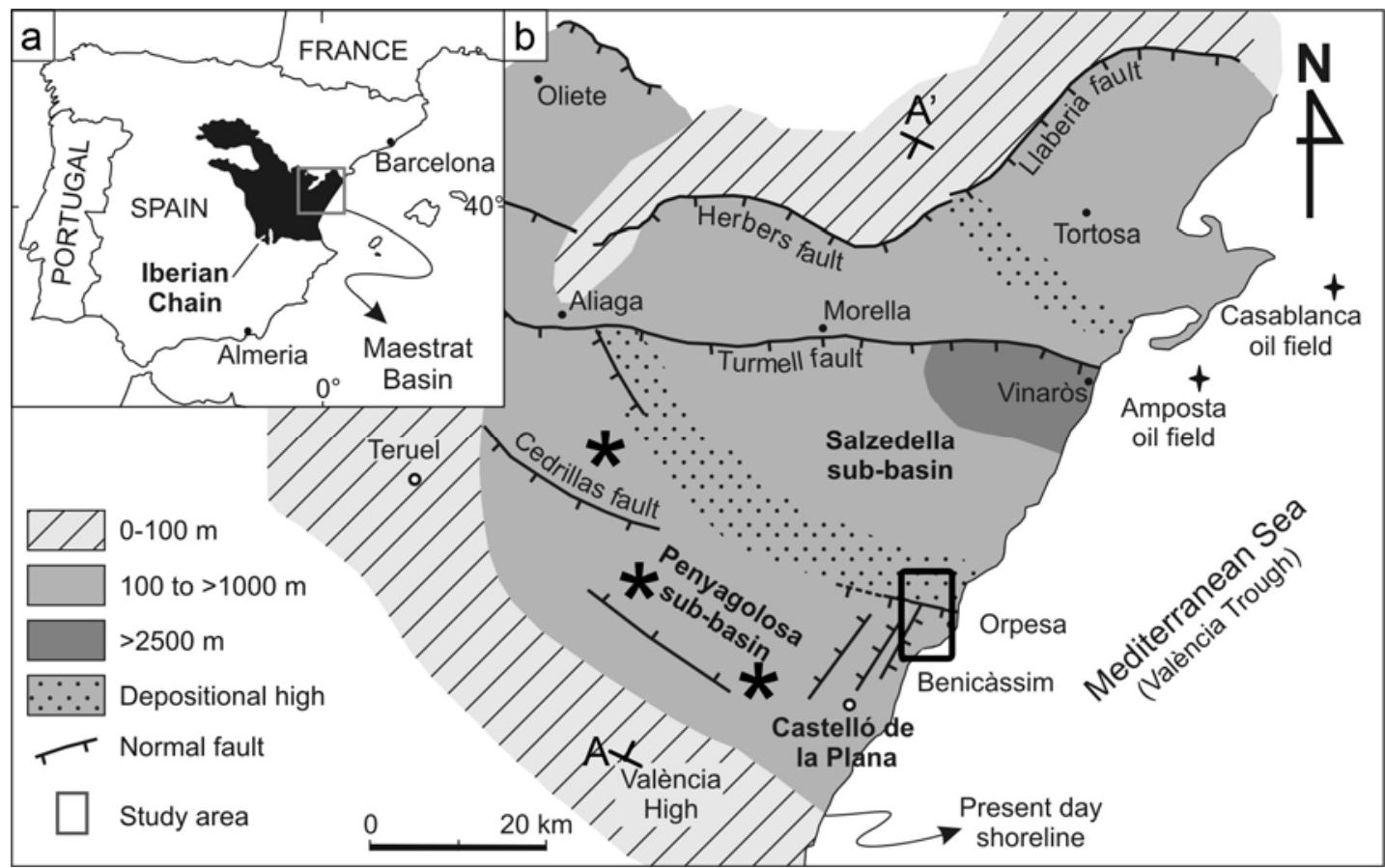

Fig. 1. (a) Simplified map of the Iberian Peninsula showing the location of the Iberian Chain and Maestrat Basin; (b) Paleogeographic map of the Maestrat Basin during the Late Jurassic - Early Cretaceous rifting cycle showing thickness of syn-rift deposits and main fault traces. The black square indicates the location of the study area, while the black asterisks show the location of dolostones of the same age and type in the Maestrat Basin. Map modified after Salas et al. (2001).

The Benicàssim outcrop analogue (Maestrat basin, E Spain) is an outstanding field example of fault-controlled dolomitization (MartínMartín et al., 2013; Corbella et al., 2014). In this area, seismic-scale stratabound dolostones extend for several kilometres away from largescale faults. Hydrothermal dolostones replace Early Cretaceous (Aptian-Albian) shallowmarine ramp limestones. This work aims at evaluating the possible $\mathrm{Mg}$ sources and quantifying the required versus available fluid volumes to account for the Benicàssim dolomitization. We first present an overview of the field area and a summary of the Benicàssim dolostone petrography and geochemistry. We then present and discuss new stable $\delta^{13} \mathrm{C}-\delta^{18} \mathrm{O}$ and radiogenic ${ }^{87} \mathrm{Sr} /{ }^{86} \mathrm{Sr}$ isotope data, which are used to model the temperature and composition of the dolomitizing fluids. The reactivity of potential dolomitizing fluids is evaluated with geochemical models depending on fluid composition and temperature. Finally, we quantify and compare required versus available fluid budgets to account for the Benicàssim dolostone using mass-balance calculations. These methods and results allow a better understanding of the origin of fluids as well as the evaluation of fluid driving forces, helping in the construction of a conceptual model for high-temperature dolomitization.

\section{The Benicàssim case study}

\subsection{Geologic setting}

The Maestrat Basin formed during the Late Jurassic - Early Cretaceous rifting cycle and accumulated up to $4500 \mathrm{~m}$ of Early Cretaceous syn-rift sediments at the basin depocentre (Salas and Casas, 1993; Salas et al., 2001) 


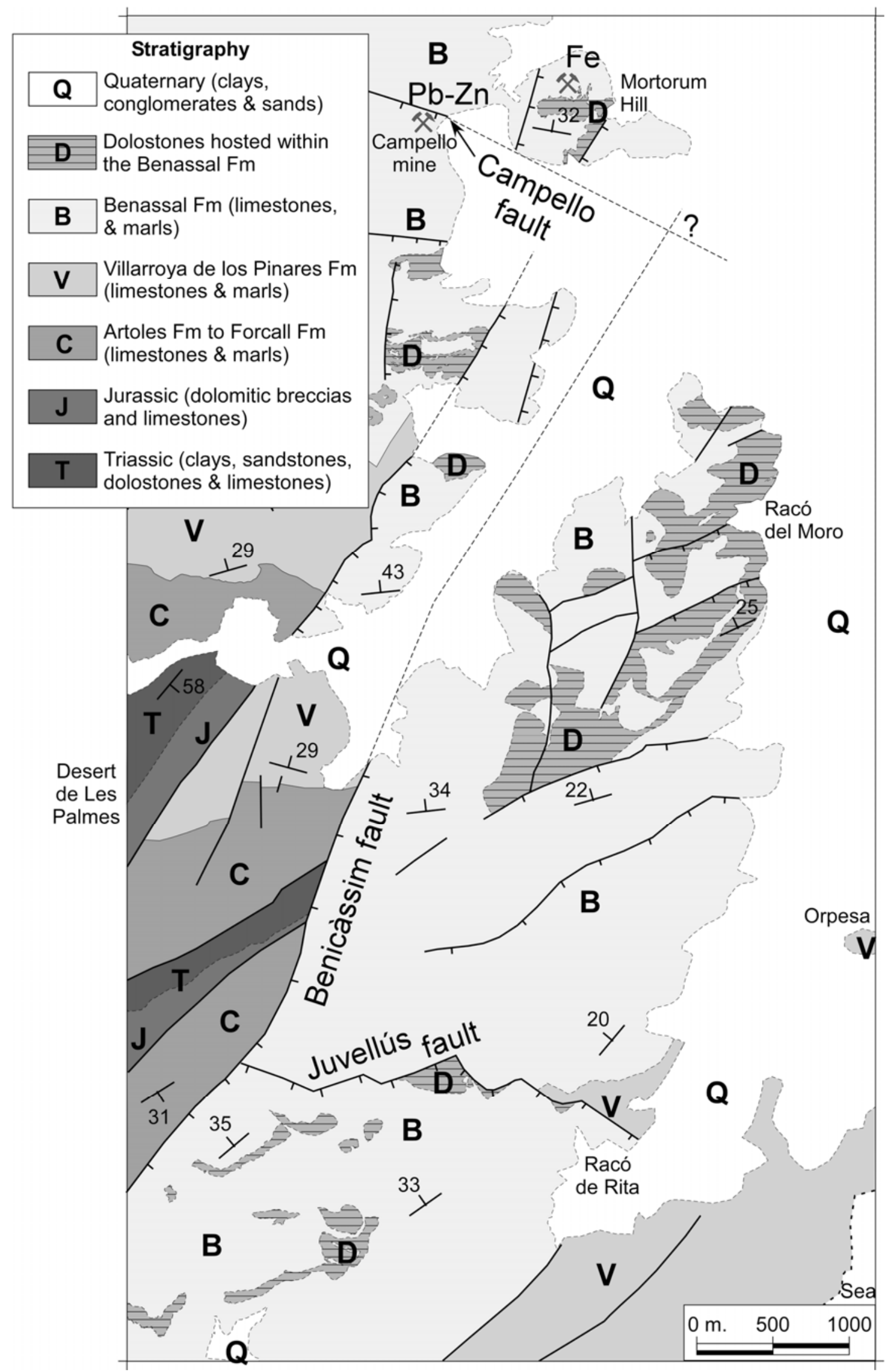

Fig. 2. Geologic map of the Benicàssim area showing the spatial patterns of dolostones and their relationship with large-scale faults. UTM coordinates of upper left corner are $4448000 \mathrm{~N}$ - 250753 E. The Desert de Les Palmes area lies west of the map, as indicated in the Figure. Map modified from Gomez-Rivas et al. (2012) and Martín-Martín et al. (2012). 
(Fig. 1). The basin was inverted during the Late Eocene - Early Oligocene into the Iberian Chain fold-and-thrust belt (Fig. 1a) (Guimerà et al., 2004). The area was also affected by a Late Oligocene - Miocene extensional period that formed the Valencia Trough and the present-day western Mediterranean basin (Roca and Guimerà, 1992).

The Benicàssim study area is located in the southern part of the Maestrat basin, constituting the eastern margin of the Desert de Les Palmes ranges (Martín-Martín et al., 2013; Fig. 2). In these ranges, the Paleozoic basement and Permian-Triassic rocks are well exposed, as well as a thin Jurassic and Lower Cretaceous cover (Simón-Gómez, 1986a; Roca and Guimerà, 1992; Roca et al., 1994; Salas et al., 2005a). The Desert de Les Palmes is characterized by NE-SW- to NNE-SSWtrending faults, which are the result of reactivation of Hercynian faults during the Early Cretaceous rifting cycle as normal faults (Salas and Guimerà, 1996). Some of these faults created the Benicàssim half graben, with a large accommodation space towards the east (Martín-Martín et al., 2013). A thick pile of Lower Cretaceous sediments (> $2000 \mathrm{~m}$ ) was deposited in the graben, while the Desert de Les Palmes area (west of Benicàssim) remained a sedimentary high.

Two sets of large-scale faults controlled sediment deposition and later fluid circulation in the Benicàssim area: the Campello (E-Wtrending and S-dipping) and Benicàssim (NNE-SSW-trending and E-dipping) fault systems (Salas, 1987; Roca and Guimerà, 1992; Roca et al., 1994; Gomez-Rivas et al., 2012; Martín-Martín et al., 2013) (Fig. 2). The two fault systems are very likely Hercynian in origin (Roca et al., 1994) and were reactivated during the Mesozoic as normal faults. They subsequently acted as strike-slip and reverse oblique-slip faults during the Tertiary inversion and were reactivated again as normal faults during the Neogene extension episode (Simón-Gómez, 1986a; Gomez-Rivas et al., 2012).

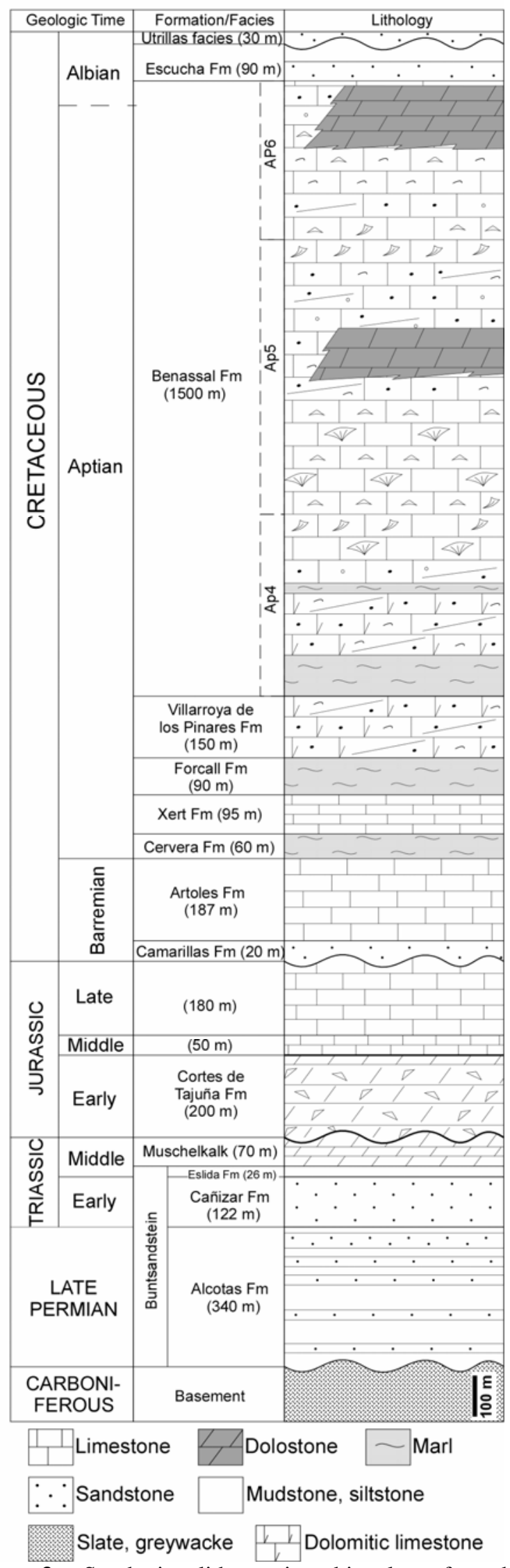

Fig. 3. Synthetic lithostratigraphic log for the Benicàssim area. The stratigraphic position of the replacement dolostones in Aptian-Albian rocks of the Benassal Fm are indicated in dark grey. 


\subsection{Rock units}

Several rock units crop out in the Desert de Les Palmes area (Simón-Gómez, 1986b; Roca et al., 1994; Martín-Martín, 2004), and are also present in the Benicàssim half graben, below the Lower Cretaceous carbonates (Figs. 2, 3): (i) Carboniferous shales that constitute the top of the Hercynian basement, (ii) Permian to Lower Triassic continental red beds (Buntsandstein facies), (iii) Middle Triassic limestones and dolostones (Muschelkalk facies), (iv) a very thin unit (few meters) of Upper Triassic continental red beds (Keuper facies), (v) Lower Jurassic partially dolomitized carbonate breccias (Cortes de Tajuña Fm) that were unconformably deposited on top of underlying units, including the basement, and (vi) Middle to Upper Jurassic limestones. It is important to notice that the thicknesses of these units are variable across the field area, with averages given in Figure 3.

The stratigraphy of the Benicàssim area is shown in Figure 3, which is based on data by Simón-Gómez (1986b), Roca et al. (1994), Martín-Martín (2004) and Martín-Martín et al. (2013). The Aptian-to-Albian succession of the area represents one of the thickest carbonate deposits of this age reported from the northern Tethyan margin (Martín-Martín et al., 2013). The Benassal formation was deposited between Late Aptian and Albian times (Moreno-Bedmar et al., 2009; 2010; Garcia et al., 2013; Martín-Martín et al., 2013). Its thickness varies across foot- and hanging-wall blocks of the Benicàssim and Campello faults, reaching a maximum of 1500 $\mathrm{m}$ in the Orpesa Range (Fig. 3), in the hanging wall the two large faults. The Benassal Fm consists of ramp-type shallow-marine limestones with orbitolinid foraminifera, rudist bivalves, corals and algae-rich facies (Salas et al., 2005a; Tomás, 2007; Tomás et al., 2007; 2008; Bover-Arnal et al., 2009a; 2009b; Martín-Martín et al., 2010; 2013). The succession is stacked into three transgressiveregressive sequences, the transgressive lithofacies being dominated by basinal marls, spicule mudstones to wackestones and orbitolinid wackestones, and the regressive lithofacies dominated by coral limestones, peloidal and bioclastic packstones, ooidal grainstones and rudist floatstones-rudstones (Fig. 3). The Benassal Fm is overlain by the Escucha Fm, which consists of $\sim 90$ m-thick clay with occasional sandy layers (e.g. Rodríguez-López et al., 2007).

\subsection{Dolostone distribution}

Dolostones in Benicàssim form seismicscale stratabound geobodies that, at present day, extend up to $7 \mathrm{~km}$ away from large-scale faults and only affect the two uppermost transgressive-regressive sequences of the Benassal Fm. The largest exposed dolostones are located in the hanging walls of the Campello and Benicàssim faults (Fig. 2). The dolomitized bodies have a thickness of tens of meters, but some of them reach $150 \mathrm{~m}$. Dolostone and limestone layers can be clearly distinguished in the field, due to their characteristic brownish and grey-blue outcrop colour, respectively (Fig. 4). Dolomitization fronts are very sharp and roughly parallel to bedding, although they undulate cutting bedding surfaces from centimetres to a few metres (Fig. 4b). Generally, non-replaced tight micritic facies or early-cemented graindominated facies appear intercalated within the dolomitized rocks (Martín-Martín et al., 2010; 2013). Replacement mostly affects bioclastic wackestones to packstones and peloidal packstones to grainstones (Fig. 5a). The permeability differences between layers associated with the original depositional facies and early diagenesis probably enhanced a strong lateral fluid flow along preferred layers, favouring the stratabound dolostone geometry away from faults, which must have acted as feeding points (Gomez-Rivas et al., 2010a; Martín-Martín et al., 2013; Corbella et al., 2014).

\subsection{Dolostone petrography and geochemistry}

Dolostones are characterized by the typical burial paragenesis with the following main 
events: calcite and dolomite cementation, host limestone replacement, post-replacement dolomite and calcite cementation, and MVT sulphide mineralization (Martín-Martín et al., 2010; 2013). Early-stage burial calcite and dolomite cementation precedes dolomitization, playing an important role in subsequent dolostone formation and distribution (Fig. 5b). Pre-replacement dolomite cements mainly affect packstones and grainstones of some specific layers. Dolomitization occurred during burial diagenesis after mechanical compaction and fracturing. Stylolites formed mostly before replacement, as well as many fractures of various scales oriented parallel to the two main faults. Most of the Benicàssim dolostone is a replacive fabric-retentive burial dolomite with low intercrystalline porosity (Fig. 5c). Dolomite crystals are planar-s to nonplanar-a, with a cloudy appearance and polymodal size distribution, a crystal size of 50 to $600 \mu \mathrm{m}$ and a relatively high Fe content (up to 3\%). The replacive dolomite was recrystallized by successive dolomitization fluids, producing a slight increase of crystalsize and intercrystalline porosity (Fig. 5d). Dissolution soon after dolomitization generated abundant porosity in dolostones, which was followed by precipitation of dolomite rim overgrowths (Fig, 5e).
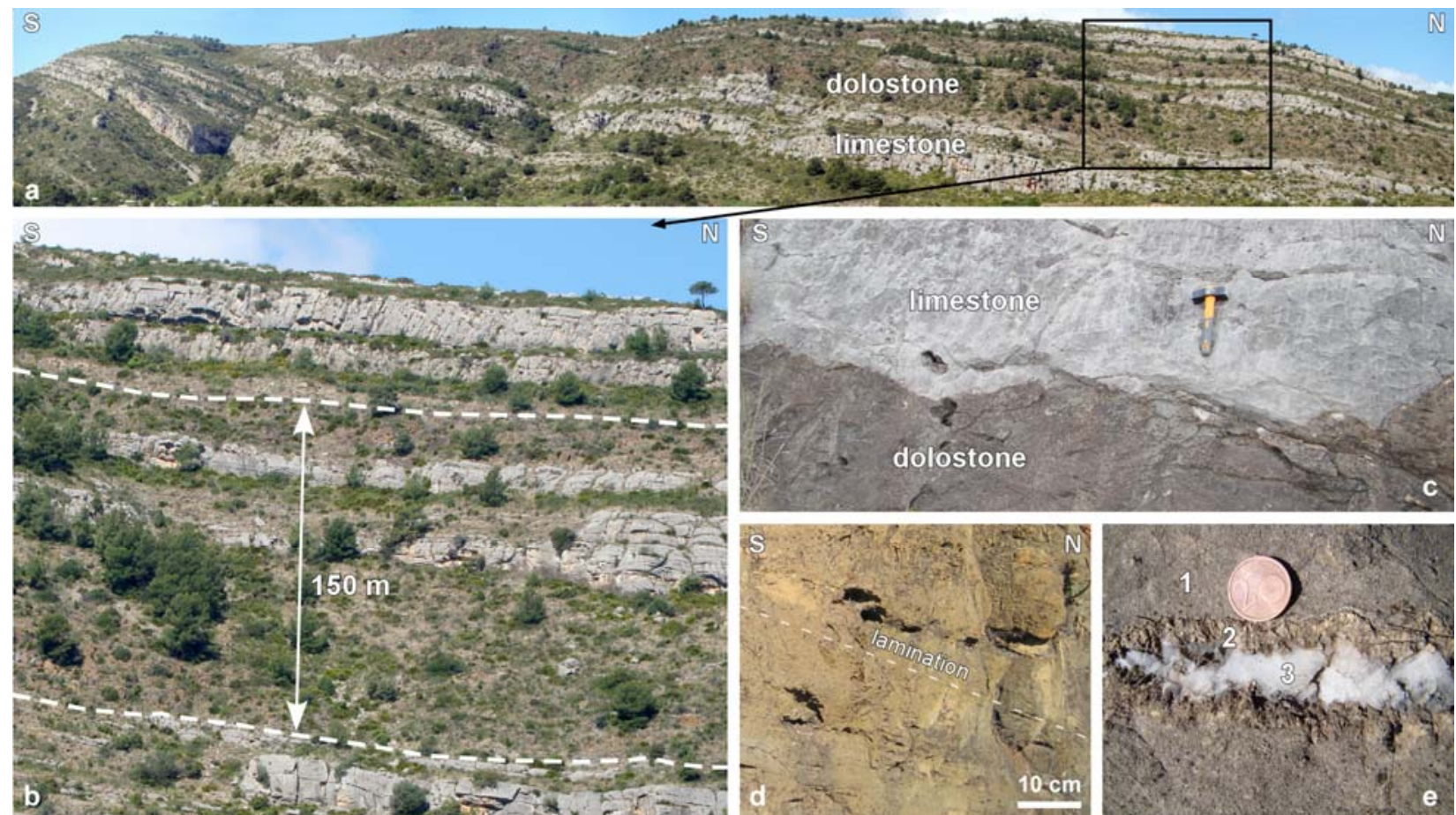

Fig. 4. Field images of the Benassal Fm limestone and dolostone. (a) Panoramic view of the Racó del Moro outcrop. Limestone and stratabound dolostone layers have distinct colour. Lateral field of view is $\sim 4 \mathrm{~km}$. (b) Zooming in the rectangle of photo (a). (c) Detail of a typical limestone-dolostone front in the area. (d) Dolomitized grainstone preserving the original lamination. (e) Detail of a high-temperature vein: (1) host replacement dolostone and (2) saddle dolomite and (3) high-temperature calcite filling an open vug.

The dolostones of the Benassal Fm locally host Mississippi Valley Type ore deposits (galena and sphalerite) and Fe-oxide mineralizations (Martín-Martín et al., 2013). The mineralizations are approximately located at the intersection between the Benicàssim and Campello faults (Fig. 2), suggesting that this was the main conduit for the upwards circulation of deep fluids. According to
Martín-Martín et al. (2010), acidic fluids derived from the emplacement of the MVT mineralization increased dolostone porosity by dissolution. The MVT deposits are associated with a fractured and brecciated karst system and are predated by saddle dolomite and calcite cements filling vugs and fractures (Fig. 5f). Different sets of Alpine and Neogene fractures overprint dolomitization (Gomez- 
Rivas et al., 2012). Meteoric calcite cements precipitated from surface-derived fluids (Fig. $5 e)$ and produced partial calcitization of the dolostones during uplift and subaerial exposure (Martín-Martín et al. 2013).

Dolomitization at Benicàssim was caused by high-temperature fluids (Martín-Martín et al., 2010; Gomez-Rivas et al., 2010b), as indicated by: (1) progressive $\delta^{18} \mathrm{O}$ decrease with dolomitization (e.g. Allan and Wiggins, 1993), (2) dominant non-planar dolomite textures (e.g. Gregg and Sibley, 1984), (3) sharp and irregular dolomitization fronts (e.g. Machel, 2004), (4) occurrence of saddle dolomite synchronous with replacement dolomite (e.g. Warren, 2000) and (5) close association with MVT deposits and hightemperature calcite cements (Gregg, 2004).
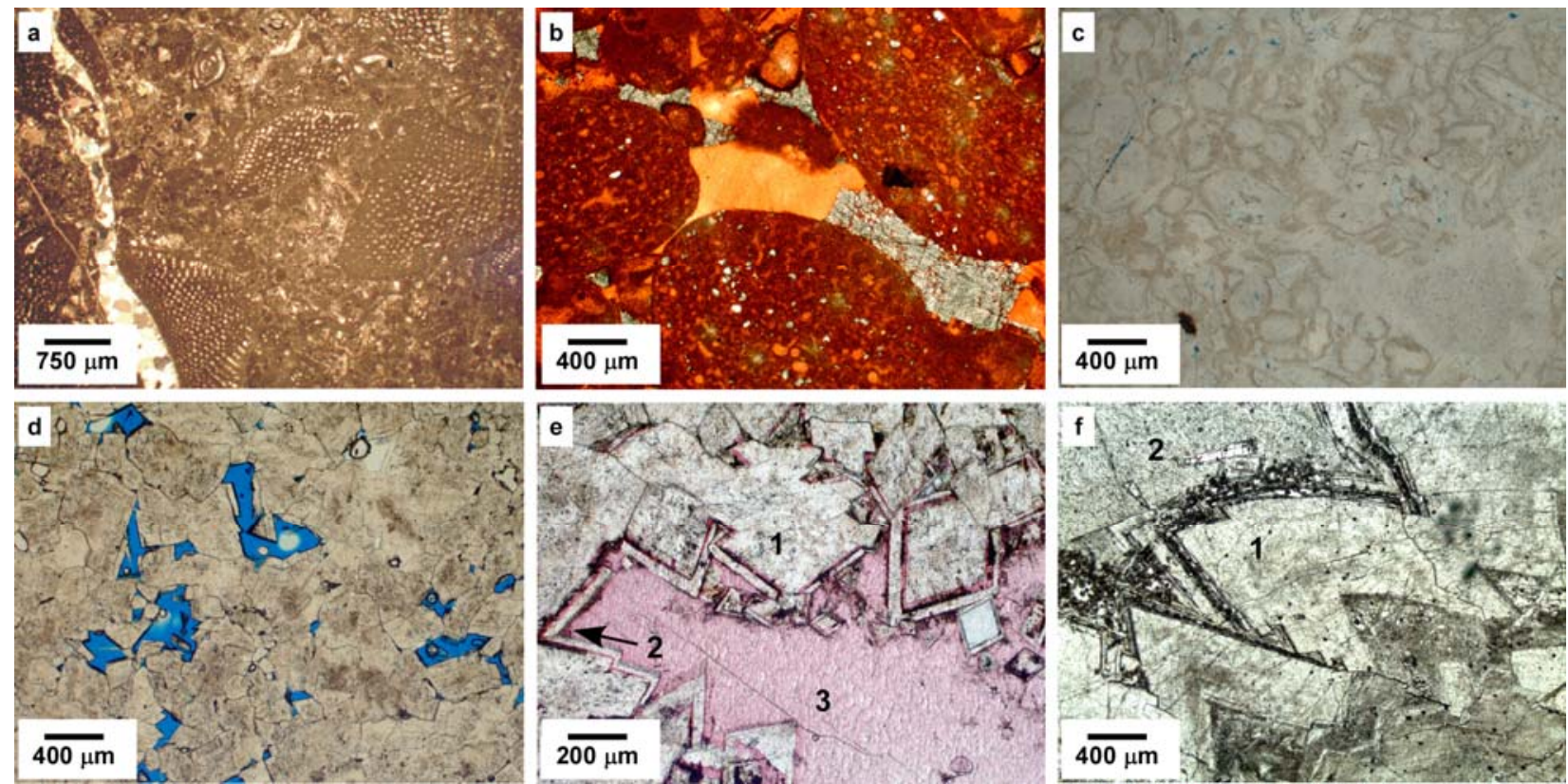

Fig. 5. Photomicrographs of the Benassal Fm limestone and dolostone. (a) wackestone with orbitolina and miliolids, a calcite vein cross-cuts the sample (PPL); (b) Coarse grain orbitolinid grainstone showing calcite (orange) and dolomite (grey) cement completely filling primary intergranular porosiy. Stained with Alizarin Red-S (PPL); (c) Replacive dolomite 1 showing the complete replacement of a fine grained peloidal grainstone (mimetic texture). Note the concavo-convex contacts between the original components, which suggest replacement after compaction, and the scarce intercrystalline porosity (light blue). Diffused light; (d) Replacive dolomite 2 showing abundant intercrystaline porosity. Note cloudy centres and clear borders in dolomite crystals (PPL); (e) replacive dolomite (1), dolomite cement rim overgrowth (2) and meteoric calcite cement (3) filling the remaining intracrystalline porosity (PPL); (f) saddle dolomite (1) postdated by ore-stage calcite cement (2).

Characterization of the fluid composition is limited by the poor quality of fluid inclusions in the Benicàssim dolomite crystals. Nevertheless, Nadal (2001), Grandia (2001) and Grandia et al. (2003) reported homogenization temperatures between 85 and $153^{\circ} \mathrm{C}$ and melting ice temperatures of $-23^{\circ}$ to $-14{ }^{\circ} \mathrm{C}$ from dolomite replacing Early Cretaceous limestones in different parts of the Maestrat basin (see Fig. 1 for location of these dolostones). According to halogen ratio data, the dolomitizing fluid was evaporated seawater that interacted with K-rich minerals, as pointed out by the high salinity and $\mathrm{Na}$ depletion (Grandia, 2001), probably Kfeldspar from the underlying basement rocks. This hypothesis is supported by the radiogenic ${ }^{87} \mathrm{Sr} /{ }^{86} \mathrm{Sr}$ signature of dolostones. Mixing of two fluids was suggested as the ore-stage minerals precipitation mechanism: a highsalinity brine at temperatures higher than $120^{\circ} \mathrm{C}$ and a low-salinity fluid at $40^{\circ} \mathrm{C}$ (Grandia, 2001; Grandia et al., 2003).

\subsection{Dolomitization conditions}

Dolomitization in Benicàssim took place at some time between the end of the Benassal Fm 
deposition (Albian) and the onset of MVT mineralization during the Paleocene, dated at 62.6 $\pm 0.7 \mathrm{Ma}$ using U-Pb dating of cogenetic calcite and galena (Grandia et al., 2000). More precisely, field and petrographic observations as well as geochemical data point towards a burial replacement after strong compaction and early diagenesis (see section 2.4). Thus, replacement probably occurred towards the end of the Cretaceous or in the very early Paleocene. Quantitative subsidence curves indicate that the burial depth in this time span ranged between 200 and $1000 \mathrm{~m}$ for the dolomitized upper Benassal carbonates (Martín-Martín et al. 2010; 2013). These depths match paleodepth values estimated by Kulzer (2011) from sedimentary (i.e. beddingparallel) stylolites. This author used the methods of Koehn et al. (2007; 2012) and Ebner et al. (2010) to analyze the morphological features of bedding-parallel stylolites and quantify the stress, compaction conditions and depth at which they formed.

Permanyer et al. (2000) calculated a geothermal gradient of $27{ }^{\circ} \mathrm{C} / \mathrm{km}$ for the Late Jurassic to Early Cretaceous rifting period and of $30{ }^{\circ} \mathrm{C} / \mathrm{km}$ for the Late Albian to Maastrichtian post-rifting stage in the Maestrat basin. More recently, Caja et al. (2009) estimated a geothermal gradient of 30 to $35^{\circ} \mathrm{C} / \mathrm{km}$ for Early Cretaceous times. Therefore, host rock temperatures of the Benicàssim Aptian-Albian carbonates during dolomitization should have been less than 60 ${ }^{\circ} \mathrm{C}$, if we only consider conductive heat transfer associated with the regional geothermal gradient. However, as mentioned above (see section 2.4), the existing geochemical data indicate that dolomitizing fluids in this area were warmer than that, up to at least $110^{\circ} \mathrm{C}$.

Dolomitization reactive transport models applied to the Benicàssim case study showed that hundreds of thousands to millions of years were necessary to completely dolomitize kilometre-long limestone sections in the area (Corbella et al., 2014), assuming flow velocities on the order of meters per year.
Such velocities are commonly assumed in sedimentary basins (e.g. Garven et al., 1993). Seawater-derived solutions flowing laterally through strata at such velocities can account for the stratabound dolomitization, although fluid velocity differences of at least two orders of magnitude were required to preferentially replace only some of the layers. This differential dolomitization along strata could be obliterated by a long-term dolomitizing fluid flow producing massive dolomites. Fluid and heat flow numerical simulations of the Benicàssim area (Gomez-Rivas et al., 2010a) indicate that a long-term fluid circulation mechanism, due to differences in pressure and temperature within the basin, could pump enough dolomitizing fluids at high temperature during long periods of time. On the contrary, the models suggest a pulsating flow system could not provide enough heat for the Benicàssim dolomitization, as fluids cool down quickly when flowing upwards along faults.

\section{Methods}

Two groups of methods have been used: isotope analysis and quantitative modelling. The first group encompasses the acquisition of stable C-O and radiogenic Sr isotopic data, and the subsequent calculation of isotope fractionation trajectories and estimation of dolomite formation temperatures. The second group includes modelling of the reactivity of possible dolomitizing fluids, the quantification of required fluid volumes to account for the Benicàssim dolomitization, and its subsequent comparison with those that could be produced from different sources.

\subsection{Stable and radiogenic isotopes}

46 samples of the host Aptian-Albian limestone, replacive dolomite, saddle dolomite as well as burial/ore-stage and meteoric calcite were selected for $\mathrm{C}$ and $\mathrm{O}$ isotopic analysis following the method of McCrea (1950). $\mathrm{CO}_{2}$ was extracted by reaction of the carbonate sample with phosphoric acid at $50^{\circ} \mathrm{C}$. The collected gas was analysed in a Finnigan MAT 
Delta S thermal ionization mass spectrometer at the Technical-scientific Laboratories of the University of Barcelona. The standard deviation of measurements was 0.03 for $\delta^{13} \mathrm{C}$ (\% PDB) and 0.06 for $\delta^{18} \mathrm{O}$ (\% SMOW). Isotope fractionation trajectories were calculated following the equations of Zheng and Hoefs (1993). The fractionation equations of water-calcite (O’Neil et al., 1969), $\mathrm{H}_{2} \mathrm{CO}_{3}$ calcite (Chacko et al., 1991), water-dolomite (Zheng, 1999) and $\mathrm{H}_{2} \mathrm{CO}_{3}$-dolomite (Zheng, 1999) were employed.

Radiogenic $\mathrm{Sr}$ isotopes $\left({ }^{87} \mathrm{Sr} /{ }^{86} \mathrm{Sr}\right)$ were analyzed on 7 samples: host-rock limestone, replacive dolomite, saddle dolomite, burial/ore-stage calcite, and a meteoric calcite related to uplift and subaerial exposure. Carbonates were dissolved in $2.5 \mathrm{~N} \mathrm{HCl}$ at 80 ${ }^{\circ} \mathrm{C}$, dried, and redissolved using $2.5 \mathrm{~N} \mathrm{HCl}$. Sr aliquots were obtained using cation exchange resins, and analyzed in a Thermal VG SECTOR 54 mass spectrometer. The reproducibility of the results $(2 \sigma)$ was always better than $\pm 0.00004 \%$. Samples were processed at the laboratories of the Universidad Complutense de Madrid. The results were controlled by repetitive analysis of the NBS-987 standard, averaging 0.710260 $\pm 0.00004(2 \sigma, n=7)$.

\subsection{Reactivity of dolomitizing fluids}

Geochemical simulations were carried out to evaluate the dolomitization capacity of different fluids at variable temperatures. The method is based on the concept of pore volume (Land, 1985), assuming that dolomitizing fluids would quickly equilibrate with the host limestone in a close system, because of the fast reaction kinetics of carbonate minerals (e.g. Sjöberg, 1976; Plummer et al. 1978), losing its dolomitization capacity. A pore volume of fluid is defined as the volume of fluid that saturates the rock's porosity. The volume of dissolved calcite in the rock and precipitated dolomite from that fluid filling the porosity is then calculated by bringing the system to equilibrium at a given temperature. The number of pore volumes calculated to completely dolomitize the rock would be the minimum volume of fluid required, assuming $100 \%$ reaction efficiency and mole-by-mole replacement. The calculation is performed in three steps. First, original fluid chemical compositions are recalculated by equilibrating them with calcite, considering the fluid has already flowed through limestones. After that, the moles of calcite and dolomite dissolved/precipitated from the fluid from/to a certain volume of rock is quantified by bringing it to equilibrium with both minerals at a given temperature. Finally, the fluid pore volumes required to replace all calcite by dolomite at the given volume is estimated. Pore volume values can be then converted to fluid/rock ratios required to completely dolomitize a certain rock volume. The advantage of giving the results in terms of fluid/rock ratios instead of pore volumes is that they are porosity-independent.

The calculations were performed using two different approaches and two codes, to compare the obtained results. For the first approach, we used the computer code PHREEQC (Parkhurst and Appello, 1999), with the thermodynamic constants of the EQ3NR database (Wolery, 1992). For the second approach, we used the reactive transport code RETRASO (REactive TRAnsport of SOlutes; Saaltink et al. 1998). In this case, we created $1 \mathrm{~m}^{3}$ models (closed systems) with certain porosity filled by the considered fluids. The moles of dissolved/precipitated calcite/dolomite were calculated by bringing the fluid to equilibrium with the host rock. RETRASO incorporates aqueous complexation, adsorption and mineral precipitation/dissolution. We ran separate sets of simulations: (1) applying thermodynamic laws, considering local equilibrium, and (2) using kinetic rates. The thermodynamic constants in RETRASO are those of the EQ3NR database (Wolery, 1992). We used dissolution/precipitation kinetic constants of $4.64 \cdot 10^{-7} \mathrm{~mol} \mathrm{~m}^{-2} \mathrm{~s}^{-1}$ for calcite (Inskeep and Bloom, 1986) and $2.20 \cdot 10^{-8} \mathrm{~mol} \mathrm{~m}^{-2} \mathrm{~s}^{-1}$ for dolomite (Ayora et al., 1998). The activity coefficients of aqueous species were computed 
with the B-dot form of the extended DebyeHückel equation of Helgeson \& Kirkham (1974), which allows the extension of the applicability to higher temperature and salinity fluids.

\subsection{Released fluid budget calculations}

The volume of fluid required to dolomitize the host rock can be compared with the volume of available fluids that could have been sourced under three different scenarios. Similar calculations, applied to ore deposits, were presented by Staude et al. (2009) and Weisheit et al. (2013). We used the model of Staude et al. (2009) to quantify fluid budgets produced by (a) release of overpressured fluids due to decompression, and (b) release of fluids due to heating.

In the first case, overpressure of the pore fluid arises from the different compressibility of fluid and solid rock. When rocks decompress, their pore volume increase is negligible. Pore-fluid pressure thus remains effectively unchanged. If pore fluids were in equilibrium before decompression, they will be out of equilibrium afterwards. Part of the fluid (the "excess volume" of Staude et al., 2009) will be released to regain equilibrium. Decompression can result from exhumation (reduction of overburden height, and hence pressure) and/or an extensional stress field that reduces the average stress, and hence pressure.

In the second case (b), an excess volume is caused by the higher thermal expansion of fluids than of the solid rock, so that heating may also result in pore fluid overpressure, which leads to release of fluids to regain equilibrium. Heating can be caused by a change in the geothermal gradient (e.g. by thinning of the crust) or by a deep heat source such as an igneous intrusion. Decompression by exhumation is instantaneous, whereas thermal equilibration is a slow process. Crustal thinning can first lead to fluid release by decompression, followed by release due to heating.
A third potential cause for fluid release is the breaking of a seal, which can lead to fluid release in order to reduce the pore-fluid pressure to regain equilibrium, if fluids are overpressured. The upward flow of the excess fraction of fluid (i.e. the volume of pore fluid that is expelled to regain equilibrium) can take place by porous flow if porosity is interconnected. Alternatively, when porosity is not connected, release of trapped fluids can occur by the onset and linkage of hydrofractures (e.g. Secor and Pollard, 1975; Bons and Van Milligen, 2001; Staude et al., 2009). This scenario assumes overpressured fluids.

The bulk modulus difference makes aqueous fluids approximately ten times more compressible than solid rocks. In order to regain equilibrium under the new conditions the pore fluid volume has to be reduced. Moreover, if a fluid in equilibrium is heated, its volume also increases due to thermal expansion. Fluid volume increase in both cases (decompression and thermal expansion) can be determined with equation 1 for small changes in pressure and temperature (Staude et al., 2009) as,

$$
\Delta V=\frac{V}{V_{0}}=\exp ^{\alpha \Delta T-\frac{\Delta P}{K}}
$$

where $V$ is the volume of pore fluid, $V_{0}$ is a reference volume $\left(\mathrm{m}^{3}\right), \alpha$ is the thermal expansion of the fluid $\left(\mathrm{K}^{-1}\right)$, $K$ represents compressibility expressed by its bulk modulus (Pa) and $\alpha$ is fluid thermal expansion $\left(\mathrm{K}^{-1}\right)$. As compressibility and thermal expansion of the solid rock are negligible when compared with that of water, Eq. (1) does not include those terms.

In order to calculate expelled fluid volumes according to the different scenarios, we have estimated the thickness of the different units when dolomitization took place. For that purpose, we have used the methods of Sclater and Christie (1980) and Schmoker and Halley (1982) to determine decompaction using density values and porosity/depth relationships (c factors) for each lithologic type. The age 
and thickness of the different units have been estimated from field data (Bover-Arnal et al., 2009a; Martín-Martín et al., 2013) and regional geology (Obis et al., 1973; Salas and Casas, 1993; Salas and Guimerà, 1996; Salas et al., 2001; Roca et al., 1994; Martín-Martín, 2004). A bulk modulus of $2 \mathrm{GPa}$ has been assumed. Water thermal expansion coefficients $(\alpha)$ have been estimated depending on fluid pressure $\left(P_{f}\right)$ and temperature $(T)$ using a linear function assuming a value of $8.8 \cdot 10^{-5} \mathrm{~K}^{-1}$ at $P_{f}=0.1 \mathrm{Mpa}$ and $T=10^{\circ} \mathrm{C}$ (Lide, 2010) and a value of $2.4 \cdot 10^{-4} \mathrm{~K}^{-1}$ at $P_{f}=25 \mathrm{Mpa}$ and $\mathrm{T}=300^{\circ} \mathrm{C}$ (Tester and Cline, 1999).

\section{Results and discussion}

The combination of the aforementioned techniques allows a multidisciplinary study of the dolomitizing fluid origin, its reactivity, the conditions under which the reaction takes place, and eventually, the comparison between fluid budgets required to dolomitize the Benicàssim rocks and the ones available from possible sources. The final outcome of the study is a conceptual model for the Benicàssim dolostones, with a quantitative evaluation of its plausibility.

\subsection{Temperature and composition of the Benicàssim dolomitizing fluid}

The isotopic composition of the original Late Aptian - Early Albian limestone is $\delta^{13} \mathrm{C}=$ $+6.2 \%$ V-PDB and $\delta^{18} \mathrm{O}=+28.3 \%$ VSMOW, inferred from the analysis of an unaltered rudist shell. However, other host limestone samples show $\delta^{13} \mathrm{C}$ values from -0.4 to $+2.7 \%$ and $\delta^{18} \mathrm{O}$ from +23.6 to $+26.0 \%$, Fig. 6, Table 1). These values are clearly shifted with respect to the Aptian-Albian seawater carbonates, suggesting an isotopic modification by diagenetic fluids.

Replacive and saddle dolomite isotope values are very similar, ranging between +0.5 and $+2.9 \%$ for $\delta^{13} \mathrm{C}$ and between +21.1 and +24.3 for $\delta^{18} \mathrm{O}$. They are also similar to the values of some of the altered limestone samples (Fig. 6; Table 1). The two types of calcite veins are also distinguished according to their stable isotope composition. Ore-stage calcite veins associated with the MVT mineralization and burial calcite cements have $\delta^{13} \mathrm{C}$ values of -3.1 to $+0.1 \%$ and $\delta^{18} \mathrm{O}$ of +13.2 to +19.2 , and meteoric calcite veins and cements show values ranging from -10.7 to $4.8 \%$ for $\delta^{13} \mathrm{C}$ and from +22.9 to +25.4 for $\delta^{18} \mathrm{O}$. Calcitized dolomite (dedolomite) isotope signature is similar to meteoric calcite, with values between -2.3 to $-10.4 \%$ for $\delta^{13} \mathrm{C}$ and +23.2 to +25.5 for $\delta^{18} \mathrm{O}$ (Fig. 6, Table 1 ). The calcitized dolomite and meteoric calcite vein isotope values can be explained after the precipitation from a fluid that isotopically exchanged $\mathrm{O}$ and $\mathrm{C}$ with Aptian-Albian limestone at low temperatures (typically < $50^{\circ} \mathrm{C}$ ), following the meteoric calcite line (Lohmann, 1988).

As temperature is the major parameter controlling oxygen isotope fractionation between fluids and carbonate minerals, the difference in $\delta^{18} \mathrm{O}$ between calcite from limestone, replacive and saddle dolomite and high-temperature calcite veins can be explained by water-rock interaction of a warm fluid with carbonates (Fig. 6; Table 2). With the modelled equations, the presented $\mathrm{C}$ and $\mathrm{O}$ isotope data are compatible with the precipitation of dolomite at $80-110^{\circ} \mathrm{C}$ from a fluid isotopically equilibrated with the regional limestone at different fluid to rock ratios as illustrated in Figure 6 (dashed curves). Similarly, C and $\mathrm{O}$ isotope composition of calcite veins and cements is constrained by model curves between 80 and $140^{\circ} \mathrm{C}$ (solid lines in Fig. 6). Therefore, in a $\delta^{13} \mathrm{C} / \delta^{18} \mathrm{O}$ plot, isotope data are compatible with a dolomitization process caused by warm fluids interacting with the limestone host rock. The estimated temperatures are similar to those obtained from fluid inclusions in dolostones of the same age and type in different areas of the Maestrat basin (85 - $153{ }^{\circ} \mathrm{C}$; Nadal, 2001; Grandia, 2001; Grandia et al., 2003) and also agree with isotope temperatures $\left(100-120^{\circ} \mathrm{C}\right)$ estimated by Grandia (2001) from sphaleritegalena pairs. According to our model, the 
dolomite isotopic data in Figure 6 can be explained from the interaction of a single fluid with the limestone host rock at a temperature range. Alternatively, the $\mathrm{C} / \mathrm{O}$ isotope data could be explained through fluid mixing, as invoked for the genesis of MVT mineralization (Corbella et al. 2004). If this was the case, mixing should occur at fault zones as a consequence of the different detachment levels of the sets of active large-scale faults. However, the lack of additional evidence (fluid inclusion and crush leach data) means that we cannot corroborate this hypothesis.

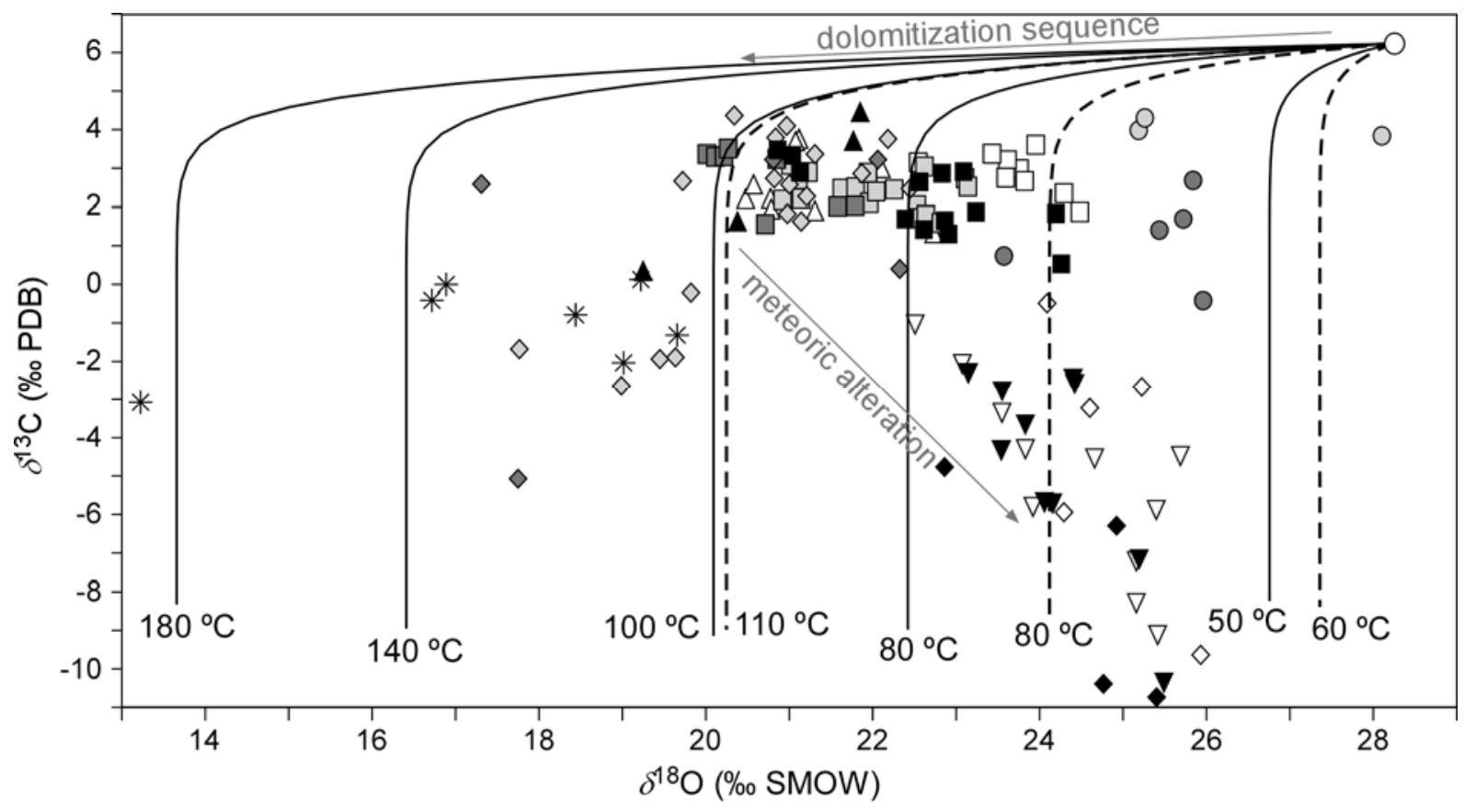

This study:

O Aptian-Abian bulk limestone

$\diamond$ Burial calcites

- Bulk dolostone

$\Delta$ Saddle dolomite

* Ore-stage calcite \& ankerite

$\boldsymbol{\nabla}$ Calcitized dolomite

$\checkmark$ Meteoric calcite
Martín-Martín et al. (2010) and Corbella et al. (2014):

$\bigcirc$ Unaltered rudist shell $\square$ Dolomitic cement

O Aptian-Abian limestone (micrite matrix) $\Delta$ Saddle dolomite

$\diamond$ Burial calcite

Recrystallized dolomite

$\square$ Replacive dolomite $\nabla$ Calcitized dolomite

$\diamond$ Meteoric calcite

Fig. 6. $\delta^{13} \mathrm{C}$ (\% PDB) vs $\delta^{18} \mathrm{O}$ (\% SMOW) plot of limestones, dolomite, calcite/dolomite cements and calcite/ankerite veins from the Benicàssim outcrops. C-O isotope model curves have been calculated in terms of fluid-rock interaction for dolomite (dashed lines) and calcite (solid lines) at different temperatures and fluid/rock ratios according to the method of Zheng and Hoefs (1993). Input data for fluid-rock exchange fractionation trajectories is shown in Table 1. The new data presented in this contribution is compared to that presented in MartínMartín et al. (2010) and Corbella et al. (2014).

The obtained ${ }^{87} \mathrm{Sr} /{ }^{86} \mathrm{Sr}$ value for host-rock limestone matches the range of late Aptian to early Albian marine carbonates (Jones and Jenkyns, 2001; Fig. 7). However, all other carbonate phases are more radiogenic, indicating the presence of a ${ }^{87} \mathrm{Sr}$-enriched fluid during precipitation of replacive dolomite, saddle dolomite as well as burial calcite cements and veins. An ${ }^{87} \mathrm{Sr}$ enrichment of hydrothermal fluids can be explained after the interaction with Rb-bearing minerals, such as clays, K-feldspar or K-mica bearing rocks. These minerals are present in the underlying Permian-Triassic and Paleozoic basement rocks, suggesting that fluids circulated through and interacted with deeper rocks before precipitating the hydrothermal carbonates. This hypothesis is in agreement with the interpretation of Sr-isotope data of replacement dolostones of the same age 
Table 1. Stable isotope data of limestone, dolomite, calcite/dolomite cements and calcite/ankerite veins. See Fig. 2 for outcrop locations.

\begin{tabular}{|c|c|c|c|}
\hline Sample & Type of sample & $\delta^{13} \mathrm{C}(\mathrm{PDB})$ & $\delta^{18} \mathrm{O}(\mathrm{SMOW})$ \\
\hline \multicolumn{4}{|c|}{ Locality: Mortorum Hill } \\
\hline 1 & Limestone (grainstone, bulk rock) & +1.7 & +25.7 \\
\hline 2 & Limestone (packstone, bulk rock) & -0.4 & +26.0 \\
\hline 3 & Limestone (packstone, bulk rock) & +0.7 & +23.6 \\
\hline 4 & Limestone (packstone, bulk rock) & +1.4 & +25.4 \\
\hline 5 & Limestone (wackestone, bulk rock) & +2.7 & +25.8 \\
\hline 6 & Replacive dolomite (bulk rock) & +0.5 & +24.3 \\
\hline 7 & Replacive dolomite (bulk rock) & +1.8 & +24.2 \\
\hline 8 & Replacive dolomite (bulk rock) & +1.9 & +23.2 \\
\hline 9 & Calcitized dolomite & -2.3 & +23.2 \\
\hline 10 & Calcitized dolomite & -10.4 & +25.5 \\
\hline 11 & Calcitized dolomite & -7.2 & +25.2 \\
\hline 12 & Calcitized dolomite & -5.7 & +24.2 \\
\hline 13 & Calcitized dolomite & -5.7 & +24.1 \\
\hline 14 & Calcitized dolomite & -2.4 & +24.4 \\
\hline 15 & Calcitized dolomite & -4.3 & +23.5 \\
\hline 16 & Calcitized dolomite & -2.6 & +24.4 \\
\hline 17 & Burial calcite cement & -5.1 & +17.8 \\
\hline 18 & Meteoric calcite vein & -6.3 & +24.9 \\
\hline 19 & Meteoric calcite vein & -10.4 & +24.8 \\
\hline 20 & Meteoric calcite vein & -10.7 & +25.4 \\
\hline 21 & Meteoric calcite vein & -4.8 & +22.9 \\
\hline \multicolumn{4}{|c|}{ Locality: Racó del Moro } \\
\hline 22 & Rudist shell in limestone (packstone) & +6.2 & +28.3 \\
\hline 23 & Replacive dolomite (bulk rock) & +1.7 & +22.4 \\
\hline 24 & Replacive dolomite (bulk rock) & +1.7 & +22.9 \\
\hline 25 & Replacive dolomite (bulk rock) & +2.9 & +21.1 \\
\hline 26 & Replacive dolomite (bulk rock) & +1.3 & +22.9 \\
\hline 27 & Replacive dolomite (bulk rock) & +1.4 & +22.6 \\
\hline 28 & Replacive dolomite (bulk rock) & +2.5 & +22.6 \\
\hline 29 & Replacive dolomite (bulk rock) & +2.9 & +23.1 \\
\hline 30 & Replacive dolomite (bulk rock) & +2.9 & +22.8 \\
\hline 31 & Saddle dolomite in moldic porosity & +4.5 & +21.9 \\
\hline 32 & Saddle dolomite in fracture & +3.7 & +21.8 \\
\hline 33 & Ore-stage calcite vein & +0.4 & +22.3 \\
\hline 34 & Ore-stage calcite vein & +3.2 & +20.8 \\
\hline 35 & Ore-stage calcite vein & +3.2 & +22.1 \\
\hline 36 & Burial calcite cement & -2.0 & +19.0 \\
\hline 37 & Burial calcite cement & -1.3 & +19.7 \\
\hline \multicolumn{4}{|c|}{ Locality: Campello mine } \\
\hline 38 & Saddle dolomite & +1.6 & +20.4 \\
\hline 39 & Saddle dolomite & +0.4 & +19.3 \\
\hline 40 & Ore-stage calcite vein & -0.8 & +18.4 \\
\hline 41 & Ore-stage calcite vein & +0.1 & +19.2 \\
\hline 42 & Ore-stage calcite vein & -0.4 & +16.7 \\
\hline 43 & Ore-stage calcite vein & +0.0 & +16.9 \\
\hline 44 & Ore-stage calcite vein & -3.1 & +13.2 \\
\hline 45 & Meteoric calcite-ankerite vein & -7.1 & +24.6 \\
\hline \multicolumn{4}{|c|}{ Locality: Racó de Rita } \\
\hline 46 & Ore-stage calcite vein & +2.6 & +17.3 \\
\hline
\end{tabular}

elsewhere in the Maestrat basin discussed by Grandia (2001), and points to a similar source for the dolomitizing fluids.
The high content of Fe in replacement and saddle dolomites (Grandia, 2001; MartínMartín et al., 2010), which was probably derived from the underlying Permian-Triassic red clays and conglomerates, may be a further 
indication of circulation of deep fluids along faults. Moreover, these red beds are laterally connected with the Early Cretaceous succession by the Benicàssim fault.

According to the aforementioned data, dolomitizing fluids were in thermal disequilibrium with the country rocks; therefore, fluids must have acquired their temperature at depths considerably greater than the host rock burial depth. Depths on the order of $1 \mathrm{~km}$ are common for the emplacement of MVT ore deposits, as is the circulation of mineralizing fluids warmer than host rocks (Grandia et al., 2003). Flow of warm fluids in the Benicàssim area during Late Cretaceous times was probably related to one of the following reasons or to both of them: (1) the existence of an igneous intrusion below the Iberian Chain or (2) the heterogeneous thinning of the Earth's crust below Iberia as a consequence of Late Permian to Triassic and Late Jurassic to Early Cretaceous rifting cycles (Salas and Casas, 1993; Salas et al., 2001; Martín-Chivelet et al., 2002). Salas et al. (2005b) proposed the existence of a hot spot that developed in relation to the opening of the oceanic North Atlantic and Bay of Biscay basins. As a consequence, an alkali basaltic volcanism would have developed in the BasqueCantabrian and Central Pyrenean areas and a deep basic pluton would have intruded below the Iberian Chain, producing thermal anomalies during the Late Cretaceous.
Thermal anomalies were common in the southern part of the Maestrat Basin during the Late Cretaceous (Salas et al., 2005b). It has been also suggested that a small rifting episode took place at the end of the Cretaceous and Early Paleocene, during the deposition of the Garumnian facies (Meléndez et al., 1985), although this hypothesis has not been confirmed. If dolomitization occurred at this stage, just before the onset of MVT deposits (dated at about 62.5 Ma by Grandia et al., 2000), deep fluids could have been released as a consequence of fault reactivation.

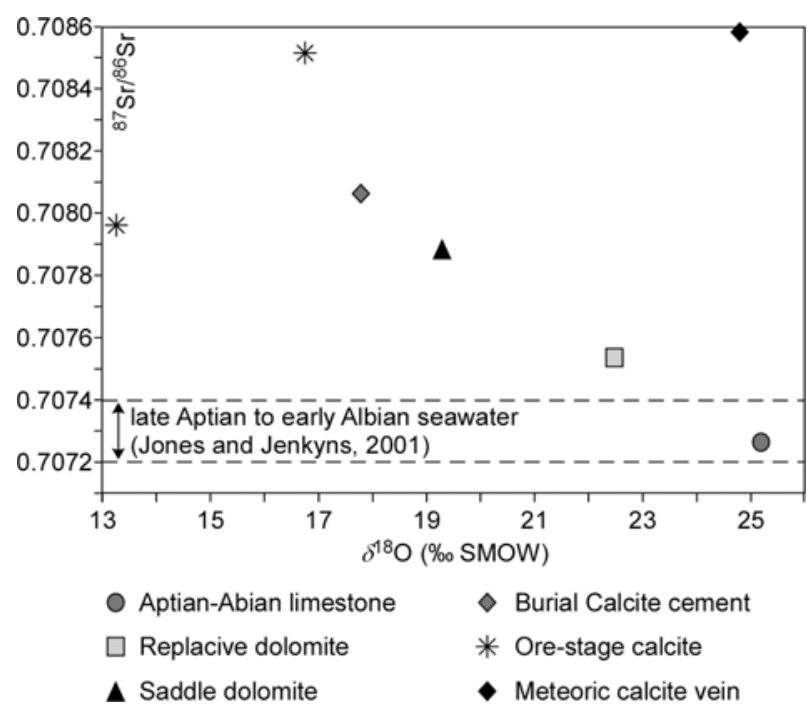

Fig. 7. ${ }^{87} \mathrm{Sr} /{ }^{86} \mathrm{Sr}$ isotope ratios vs. $\delta^{18} \mathrm{O}$ (\%o SMOW) values measured from dolomite and calcite samples at Benicàssim.

Table 2. Input data for fluid-rock exchange models presented in Fig. 6.

\begin{tabular}{llllll}
\hline Mineral & $\begin{array}{l}\delta^{13} \mathrm{C}_{\text {fluid }} \\
(\% \text { PDB })\end{array}$ & $\begin{array}{l}\delta^{13} \mathrm{C}_{\text {rock }} \\
(\% \text { PDB })\end{array}$ & $\begin{array}{l}\delta^{18} \mathrm{O}_{\text {fluid }} \\
(\% \text { SMOW })\end{array}$ & $\begin{array}{l}\delta^{18} \mathrm{O}_{\text {rock }} \\
(\% \text { SMOW })\end{array}$ & $\mathrm{X}_{\Sigma \mathrm{C}}$ \\
\hline Dolomite & -10.0 & +6.2 & +3.0 & +28.2 & $0.05\left(\mathrm{H}_{2} \mathrm{CO}_{3}\right)$ \\
Calcite & -10.0 & +6.2 & +3.0 & +28.2 & $0.05\left(\mathrm{H}_{2} \mathrm{CO}_{3}\right)$ \\
\hline
\end{tabular}

4.2. Magnesium sources and requirements for the Benicàssim dolomitization

Based on mapping (Fig. 2) and outcrop observations we have estimated that the total volume of dolomitized rock in the $\sim 60 \mathrm{~km}^{2}$ Benicàssim area was on the order of $\sim 4 \cdot 10^{9}$ $\mathrm{m}^{3}$, including rocks eroded during the Cenozoic uplift. This volume is about $\sim 6 \cdot 10^{8}$ $\mathrm{m}^{3}$ without considering the eroded material. The three mapped tabular bodies of dolostone that are visible throughout the field area, from the sedimentary high of the Dessert de Les Palmes area in the South, to the Campello fault in the North, were considered. A constant thickness and a composition of $90 \%$ dolomite and $1 \%$ porosity have been assumed. In order to account for the eroded dolostone we have 
Table 3. Summary of the different Mg sources considered in this study (see text for further details). The total amount of Mg required to dolomitize the Benicàssim Aptian-Albian limestones is $\sim 5 \cdot 10^{13} \mathrm{~mol}$.

\section{Possible Mg sources}

(a) fluids that calcitized Triassic and/or Jurassic dolomites

(b) brines that dissolved Jurassic and/or Triassic evaporites

(c) Mg-rich fluids derived from illitization of Permian-Triassic clays clays

(d) fluids derived from dewatering of Cretaceous marls and limestones

(e) deep brines (unknown origin) coming from Palaeozoic basement

(f) seawater (pristine or concentrated)

\section{Volume of
of fluid $\left(\mathrm{m}^{3}\right)$}

depends on

concentration

neglectable

neglectable

$3.64 \cdot 10^{-5}$

unknown

?

unknown

$3.64 \cdot 10^{-5}$

(pristine)

\section{$\left(\mathrm{mol} / \mathrm{cm}^{3}\right)$}

$-$

$-$
Amount of Mg available for dolomitization (mol)

$$
1.25 \cdot 10^{12}
$$

(assuming 30\% of rock

was dedolomitized)

neglectable

neglectable

?

depends on fluid volume

\section{Viable method (yes/no?)}

Not alone, but could have contributed

if calcitization of Triassic-Jurassic

rocks was synchronous with Late

Cretaceous dolomitization

No. Evaporite levels are very thin, and they do not contain Mg-rich evaporites

No. Permian-Triassic layers only have very small amounts of Mg-bearing

Not alone, but could have contributed if dolomite formed during compaction. Does not match dolomite temperature and formation time

Not alone, but could have contributed if fluid mixing occurred

Yes. Fluid volume must be quantified (see section 5.4)

The total amount of Mg required to dolomitize the Benicàssim Aptian-Albian limestones is $\sim 5.1 \cdot 10^{13}$ mol 
projected the tabular bodies on cross-sections and measured the resulting volumes. Considering stoichiometric dolomite and a mole-by-mole replacement of calcite, at least $\sim 5 \cdot 10^{13}$ moles of $\mathrm{Mg}$ would have been required to account for the partial dolomitization of the Benicàssim carbonate ramp. This amount would be about $\sim 10^{13}$ moles of $\mathrm{Mg}$ if we do not take into account the dolostone rock volumes that have been eroded as a consequence of post-dolomitization largescale fault movements and uplift.

Taking into account the rocks present in the Benicàssim and surrounding areas, the magnesium required to cause the described dolomitization could have been derived from the following fluids (Table 3): (a) fluids that calcitized the underlying Triassic and/or Jurassic dolostones, (b) brines that dissolved underlying Upper Triassic and Lower Jurassic evaporites, (c) Mg-rich fluids derived from the alteration of Permian-Triassic clay minerals, (d) fluids from dewatering of Cretaceous marls and limestones due to compaction, (e) deep brines of unknown origin that had interacted with Paleozoic basement rocks and (f) seawater, either pristine, concentrated, or evolved (by interaction with other sources).

Source (a) (fluids that calcitized Triassic and/or Jurassic dolostones) is ruled out because Triassic and Jurassic dolostones from the adjacent Desert de Les Palmes area have not been extensively calcitized. Based on thin section analysis, we have estimated that these dolostones have about 30\% calcite volume at present time. Moreover, the thickness of these units is very small compared to that of the Aptian-Albian dolostones (Fig. 3). The calculations show that the amount of Mg that could be obtained from this source is between one and two orders of magnitude less than required (Table 3 ).

Source (b) (brines that dissolved underlying Upper Triassic evaporites) is not plausible because Triassic evaporites (Keuper facies) were mostly eroded in the area before the deposition of the Aptian-Albian carbonates.
The Keuper facies unit in the Desert de Les Palmes area is only a few meters thick and probably had a maximum thickness of $50 \mathrm{~m}$ during Aptian-Albian times (Roca et al., 1994). Moreover, the only evaporite mineral containing $\mathrm{Mg}$ in the Triassic-Jurassic of the Maestrat basin is polyhalite (Ortí and Salvany, 1990). The fluid volumes that could have been produced from these sources are negligible compared to the required ones to account for the Benicàssim dolomitization.

The illitization of smectite (source c) can release magnesium (Schrijver et al., 1996). However, very small amounts of Mg-bearing clays are reported from the Permian-Triassic in the area (Martín-Martín, 2004; Martín-Martín et al., 2006), so that there could be no massive $\mathrm{Mg}$ release.

Dewatering of marls and limestones by compaction (source d) would probably liberate seawater, either pristine or evolved/concentrated, trapped within the pore system at the time of sedimentation. This process has been claimed for the dolomitization of Upper Jurassic rocks in the Swabian Alb, south-western Germany (Reinhold, 1998). In a similar way, we have estimated the fluid volume that could be expelled from Early Cretaceous rocks due to compaction (Table 3), after calculating the original pore space volume before and after burial. For this purpose, we have used the values proposed by Sclater and Christie (1980) for original carbonate porosity and the porosity-depth equation of Schmoker and Halley (1982) for porosity evolution after burial. Assuming that the porosity volume loss corresponds to the expelled fluid volume, the amount of $\mathrm{Mg}$ that could be obtained from this source is at least 50 times less than the volume required to form the estimated total volume of dolomite. Moreover, if such fluids had dolomitization potential, they would have reacted with the host limestones during their long residence time, losing their dolomitization capacity. 
(a)

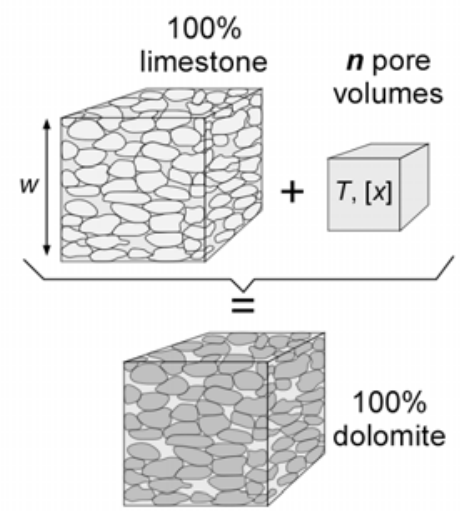

Total volume $V_{T}=w^{3}$

Pore volume $V_{p}=V_{T} \cdot \phi$

Fluid/rock ratio $=\frac{V_{\text {required fluid }}}{V_{\text {mineral }}}$
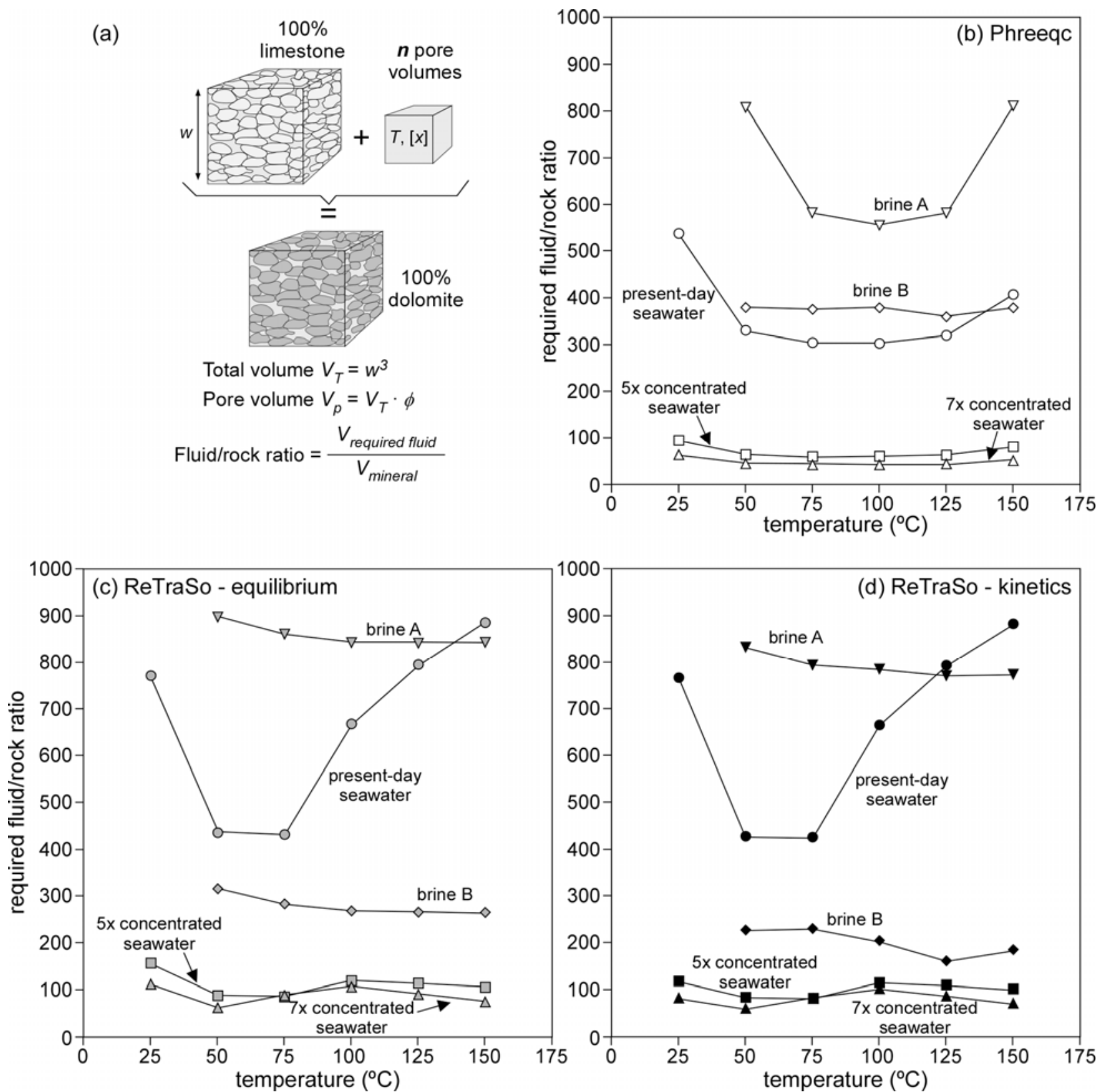

Fig. 8. (a) Sketch illustrating the concept of pore volume. A fluid with certain composition $([x])$ and at a certain temperature $(T)$ is inserted in the pore space. After reaction with $n$ fluid pore volumes the rock is completely dolomitized; (b) quantification of fluid/rock ratios that are required to dolomitize a volume of rock depending on composition and temperature. The dolomitization temperature range in the area was $\sim 80-150^{\circ} \mathrm{C}$.

Table 4. Chemical composition of the solutions used for geochemical modelling. Concentration units are in mol/kg water. References: (1) Stumm and Morgan (1981); (3) Shanks and Bischoff (1997) and (4) Kharaka and Thordsen (1992). All these fluids were equilibrated with calcite prior to calculations.

\begin{tabular}{lccccc}
\hline & $\begin{array}{c}\text { (1) Present-day } \\
\text { seawater }\end{array}$ & $\begin{array}{c}\text { (2) } 5 \text { times- } \\
\text { concentrated seawater }\end{array}$ & $\begin{array}{c}\text { (3) } 7 \text { times- } \\
\text { concentrated seawater }\end{array}$ & (4) Brine A & (5) Brine B \\
\hline $\mathrm{Ca}$ & 0.0103 & 0.0516 & 0.0723 & 0.1285 & 1.1627 \\
$\mathrm{Mg}$ & 0.0531 & 0.2654 & 0.3719 & 0.0314 & 0.1255 \\
$\mathrm{Na}$ & 0.4680 & 2.3390 & 3.2770 & 4.0279 & 2.6838 \\
$\mathrm{Cl}$ & 0.5460 & 2.7290 & 3.8240 & 4.4010 & 5.5849 \\
$\%$ wt eq NaCl & 3.5 & 17.5 & 24.5 & 25 & 32 \\
\hline
\end{tabular}


Source (e) (deep brines of unknown origin that had interacted with Paleozoic basement rocks) is impossible to quantify with the current geologic knowledge of the area. On the other hand, seawater-derived fluids (source $\mathrm{f}$ ) must have been available at any time, given that the depo-setting was mostly marine during the Cretaceous. Hence, the geochemical and geological data from Benicàssim and adjacent areas suggest that the possible sources of $\mathrm{Mg}$ are pristine/evaporated/evolved seawater (source f), basement brines (source e), which can also be seawater-derived, or a mixture of both. Dewatering of carbonates by compaction (source d) could have been an extra source of Mg or for local dolomitization (Table 3). The possible contribution of fluids derived from such sources is evaluated in detail in the following section.

\subsection{Reactivity of potential dolomitizing fluids}

The dolomitizing capacity of five types of fluids that could have sourced sufficient $\mathrm{Mg}$ (as explained above) has been compared at a temperature range between $50^{\circ} \mathrm{C}$ and $150^{\circ} \mathrm{C}$, which is a range larger than suggested by the geochemical data. These fluids are (Table 4): 1) present-day seawater, 2) a fluid that is 5 times-concentrated seawater, 3) a fluid that is 7 times-concentrated seawater, 4) brine A (Shanks and Bischoff, 1997) and 5) brine B (Kharaka and Thordsen, 1992). Late Cretaceous seawater had a lower $\mathrm{Mg} / \mathrm{Ca}$ ratio than modern seawater (e.g. Wallmann, 2001). However, we prefer to perform our estimations with present-day seawater, because its chemical behaviour is well known. If Late Cretaceous seawater was used instead, the volume of fluid required to completely dolomitize a certain rock volume would be higher. Brines A and B were selected from the literature as representative of fluids that interacted with carbonates and siliciclastic rocks at similar burial depths to the Benicàssim rocks. These brines contain relatively high $\mathrm{Mg}$ concentrations, so they can be considered to have a high dolomitization capacity.
The calculations indicate that the minimum fluid/rock ratio needed to dolomitize the Benicàssim limestone would vary between $\sim 46$ and $\sim 61$, depending on the selected method. These would correspond to 7 timesconcentrated seawater at 50 to $100{ }^{\circ} \mathrm{C}$ (Fig. 8, Table 4). The worst-case scenario would require a fluid/rock ratio of $\sim 900$, which corresponds to brine A at $50{ }^{\circ} \mathrm{C}$ (Fig. 8, Table 4). It is worth noting that the dolomitizing capacity of these solutions (Fig. 8b) is directly proportional neither to the $\mathrm{Mg}$ concentration nor to the salinity of the fluid, even though the concentrated present-day seawater, with twice more $\mathrm{Mg}$ than brine $\mathrm{B}$ and eight times more $\mathrm{Mg}$ than brine $\mathrm{A}$, has a higher dolomitizing capacity.

The optimum temperature for dolomitization (i.e. fewer pore volumes required) ranges between 75 and $125^{\circ} \mathrm{C}$ (Fig. $8 \mathrm{~b}-\mathrm{d})$. The sensitivity of fluid reactivity to temperature depends on fluid composition. In fact, fluids that are capable of dolomitizing at a certain temperature can calcitize when they are cooler (Escorcia et al., 2013). This implies that one single fluid in a basin could be responsible for both dolomitization when warm and dedolomitization when cooled to surface temperature.

\subsection{Fluid volume constraints}

Following the method of Staude et al. (2009) the estimation of fluid release for dolomitization was performed in three different end-member scenarios (Fig. 9):

(1) interstitial fluids trapped within Late Jurassic to Early Cretaceous rocks, overpressured below the uppermost marly unit at the base of the Benassal Fm (Fig. 4). For simplicity, these fluids were considered under lithostatic pressure and were decompressed as a consequence of seal breaking (Fig. 9b).

(2) interstitial fluids trapped within all rocks down to $10 \mathrm{~km}$ depth, overpressured below the uppermost 
marly unit at the base of the Benassal Fm. These fluids were at lithostatic pressure, and were decompressed as a consequence of seal breaking (Fig. 9c).

(3) interstitial fluids trapped within all rocks down to $10 \mathrm{~km}$ depth, strongly heated due to an hypothetic anomalous geothermal gradient $\left(50^{\circ} \mathrm{C} / \mathrm{km}\right)$. Gradients higher than that have been reported from several parts of the Iberian Chain during the Late Cretaceous (Salas et al., 2005b). Fluid pressure was considered to be hydrostatic, with connected porosity (Fig. 9d).

In the first two cases, the seal breaking would release fluid rapidly, in the form of a fluid burst as a consequence of fast fluid decompression due to the bulk modulus differences between fluids and host rocks. The fluids buried and compressed at the end of Early Cretaceous rifting cycle could be released during the Late Cretaceous post-rift cycle due to seal breaking as a consequence of isostatic rebound or exhumation. Fluid release could also occur due to fault reactivation during a small rift cycle during the Cretaceous - Paleocene transition (contemporaneously with the deposition of the Garumnian facies). In case (3) a high geothermal gradient, caused by either a thin Earth's crust or an igneous intrusion (Salas et al. 2005b), would warm up fluids and host rocks. In such a case, fluid release would be slower and extend over a longer period due to the fluid thermal expansion during heating. High-temperatures are reported in the whole Maestrat basin during the Late Cretaceous post-rift cycle (Tritlla, 1994; Tritlla and Cardellach, 1997; Tritlla and Solé, 1999; Tritlla et al., 2001; Grandia et al., 2000; 2003; Martín-Martín , 2004; Martín-Martín et al., 2013), so case 3 is a very plausible scenario.

The total fluid volume that could have been expelled due to a fast decompression would have been about $6 \cdot 10^{8} \mathrm{~m}^{3}$ and $4 \cdot 10^{9} \mathrm{~m}^{3}$ under scenarios (1) and (2), respectively (Table 5), in one instantaneous pulse. This volume is 3 to 4 orders of magnitude smaller than the minimum required to account for the Benicàssim dolostones, which would have been equivalent to $5 \cdot 10^{11} \mathrm{~m}^{3}$ of fluid for the most optimistic scenario (Table 5). About 6 times less fluid would be needed if the eroded dolostone volumes are not considered. However, these differences would be considerably higher if the reaction conditions were not optimal, as our required fluid volume calculations assume a mole-by-mole replacement and $100 \%$ efficiency in the dolomitization reaction (i.e. all the fluid totally reacts). The difference between required and expelled fluid would have been even higher if the pressure below the Benassal Fm was lower than lithostatic and/or if other less reactive fluids were considered. These results suggest that these scenarios can only provide a limited mass of $\mathrm{Mg}$ for the dolomitization reaction when taking into account rock volumes in the Benicàssim half graben. Therefore, even if a larger area is considered, the orders of magnitude difference between required and available fluid volumes rules out overpressured fluids as the only dolomitizing source.

As pores cannot expand as much as the fluid when heated, some excess fluid would be transported upwards through the connected pore network or by hydrofracturing under scenario (3). The calculations indicate that the volume of fluid expelled would have been on the order of $6 \cdot 10^{9} \mathrm{~m}^{3}$. This value is still 2 to 3 orders of magnitude smaller than minimum required one (Table 5). Consequently, fluid release by heating can also not be considered as the only source for the Benicàssim dolomitization fluids. The uncertainty associated with the calculations presented in this section is negligible when compared to the required versus available fluid budgets, which are different by orders of magnitude. An alternative dolomitizing fluid source and flow mechanism involving a larger area should be invoked. In a sedimentary basin, thermal convection is a very likely alternative capable of driving large volumes of fluids to the 
reaction site through faults and permeable layers during long time periods (e.g. Person et al., 1996).

\subsection{Conceptual model for the Benicàssim dolomitization}

Based on the presented field and geochemical data and the mass-balance calculations, we argue that the most plausible model for the formation of the Benicàssim high-temperature replacive dolostone includes a system in which a warm brine, derived from concentrated seawater that interacted with
Permian-Triassic rocks and/or Paleozoic basement, circulated upwards along largescale faults and high permeability beds (Fig. 9e). The most likely mechanism driving this fluid advection in Benicàssim during late Cretaceous to early Tertiary times is thermal convection. According to Morrow (1988) thermal convection can support long-lived flow systems that are capable of recycling subsurface solutions many times through the rock mass. This mechanism could have been driven by a thermal anomaly during the postrift cycle, as explained above.

Table 5. Mass-balance calculations comparing available vs. required fluid budgets to account for the Benicàssim replacement dolostone. This table shows data for the scenarios described in section 4.6.

\begin{tabular}{lcccc}
\hline fluid type & $\begin{array}{c}\text { min. required fluid/ } \\
\text { rock ratio at } 100^{\circ} \mathrm{C}\end{array}$ & $\begin{array}{c}\text { total volume } \\
\text { required }\left(\mathrm{m}^{3}\right)\end{array}$ & $\begin{array}{c}\text { total volume } \\
\text { available }\left(\mathrm{m}^{3}\right)\end{array}$ & $\begin{array}{c}\text { difference (ratio } \\
\text { required/estimated) }\end{array}$ \\
\hline
\end{tabular}

\begin{tabular}{|c|c|c|c|c|}
\hline seawater & 302 & $2.57 \cdot 10^{12}$ & $5.7 \cdot 10^{8}$ & x 4,519 \\
\hline $5 \times$ conc. seawater & 60 & $5.12 \cdot 10^{11}$ & & x 900 \\
\hline 7 x conc. seawater & 43 & $3.62 \cdot 10^{11}$ & & x 637 \\
\hline brine A & 556 & $4.73 \cdot 10^{12}$ & & x 8,310 \\
\hline brine $\mathrm{B}$ & 378 & $3.12 \cdot 10^{12}$ & & $\times 5,651$ \\
\hline
\end{tabular}

Scenario 2 - overpressured pore fluids trapped down to a depth of $10 \mathrm{~km}$ :

\begin{tabular}{|c|c|c|c|}
\hline seawater & 302 & $2.57 \cdot 10^{12} \quad 3.6 \cdot 10^{9}$ & x 704 \\
\hline $5 \mathrm{x}$ conc. seawater & 60 & $5.12 \cdot 10^{11}$ & x 140 \\
\hline 7 x conc. seawater & 43 & $3.62 \cdot 10^{11}$ & х 99 \\
\hline brine A & 556 & $4.73 \cdot 10^{12}$ & x 1,294 \\
\hline brine $\mathrm{B}$ & 378 & $3.12 \cdot 10^{12}$ & x 880 \\
\hline
\end{tabular}

Scenario 3 - pore fluids trapped down to a depth of $10 \mathrm{~km}$ and heated with a geothermal gradient of $50^{\circ} \mathrm{C} / \mathrm{km}$ :

\begin{tabular}{|c|c|c|c|c|}
\hline seawater & 302 & $2.57 \cdot 10^{12}$ & $5.7 \cdot 10^{9}$ & x 455 \\
\hline $5 \times$ conc. seawater & 60 & $5.12 \cdot 10^{11}$ & & x 91 \\
\hline $7 \mathrm{x}$ conc. seawater & 43 & $3.62 \cdot 10^{11}$ & & x 64 \\
\hline brine $\mathrm{A}$ & 556 & $4.73 \cdot 10^{12}$ & & x 836 \\
\hline brine $\mathrm{B}$ & 378 & $3.12 \cdot 10^{12}$ & & х 569 \\
\hline
\end{tabular}

In order to calculate the minimum size of the advection system that would account for the Benicàssim dolomitization, we consider a geothermal gradient of $30{ }^{\circ} \mathrm{C} / \mathrm{km}$. In the worstcase scenario of no additional heat source, a minimum depth of $5 \mathrm{~km}$ for the convection cells is needed for the fluid to reach an equilibrium temperature of $150-200^{\circ} \mathrm{C}$, which would allow for some cooling when flowing upwards. A total volume of $\sim 2 \cdot 10^{11} \mathrm{~m}^{3}$ could be stored within pores of the first $5 \mathrm{~km}$ of rocks in the Benicàssim half graben (the same porosity values as for the previous fluid budget calculations were assumed). If all this fluid volume circulated at some stage through the high permeability layers, and assuming that all fluid reacted, then an advective system approximately 3 times bigger than the Benicàssim half graben would have been required to form the dolostone geobodies. This calculation was carried out considering the most reactive dolomitizing fluid and 100\% reaction efficiency with the host rock. The rock volume involved in the advective system would probably have been larger, because not 


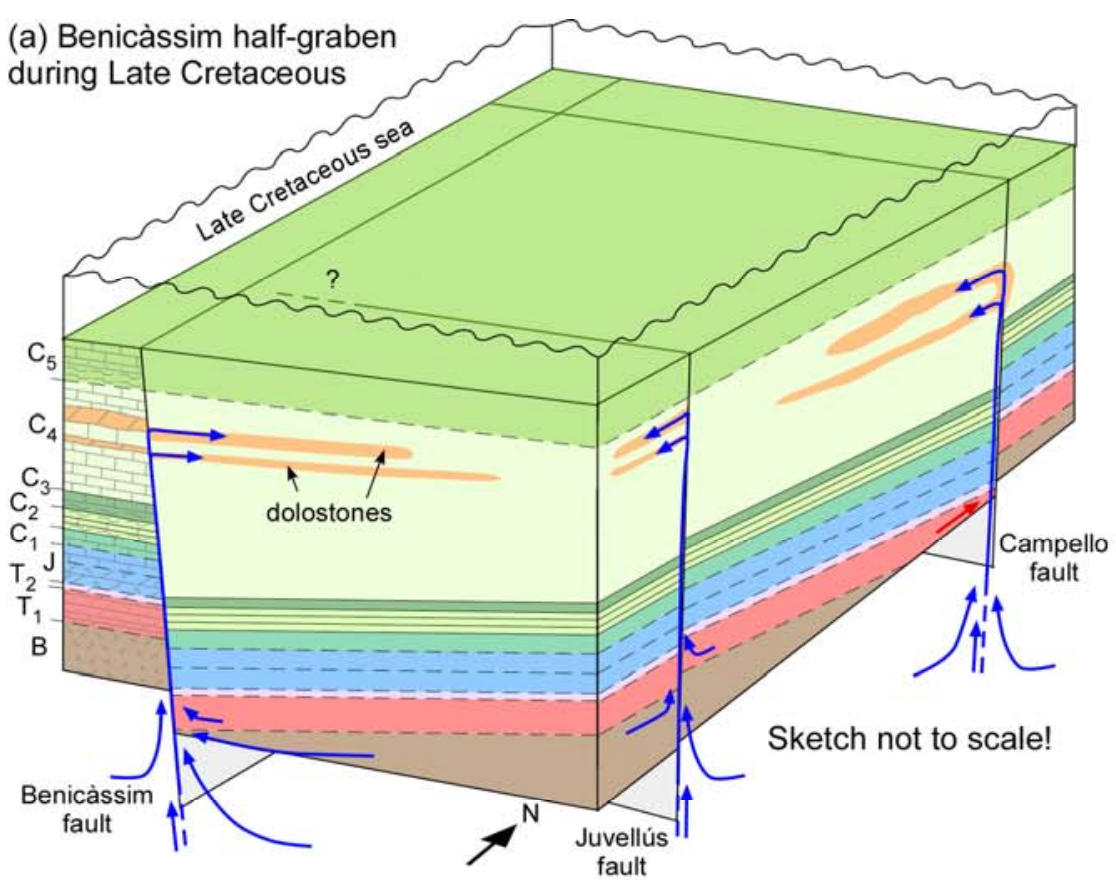

(e) Thermal convection system in the southern Maestrat Basin

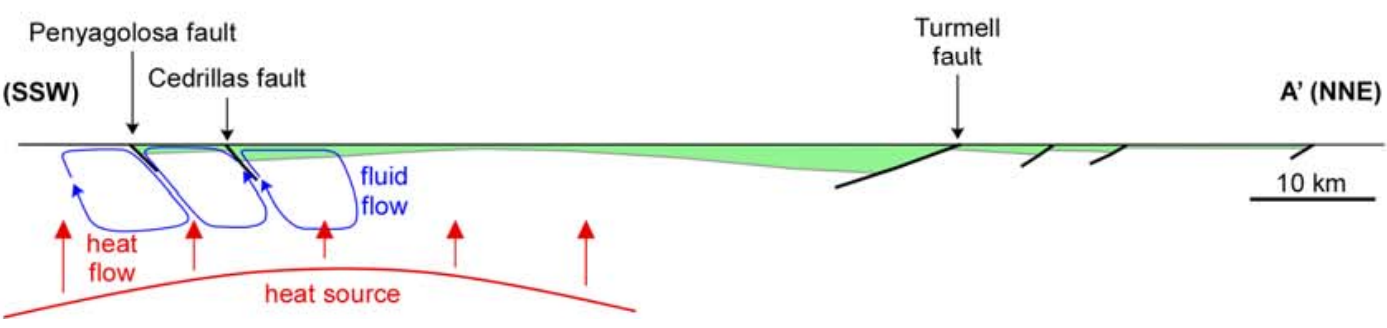

(b) Scenario (1)

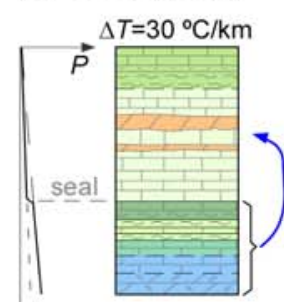

章

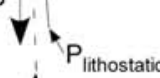

$P_{\text {hydrostatic }}$

Figure 9. (a) Sketch illustrating the Benicàssim half graben configuration during the Late Cretaceous. Arrows indicate fluid flow of deeper warm fluids that flowed upwards along large-scale faults and laterally invaded high-permeability beds, giving rise to a stratabound dolomitization pattern. (b-d) Dolomitization scenarios according to 1-D fluid release calculations: (b) scenario (1), (c) scenario (2) and (d) scenario (3). (e) SSW-NNE cross-section along the Maestrat Basin illustrating a thermal convection conceptual model for the southern part of the basin during the Late Cretaceous. The location of this cross section is indicated by the line A-A' in Fig. 1. 
all the fluid reacts until reaching equilibrium in a convection cell. The presence of dolostones of the same type and age in other parts of the Maestrat basin (Nadal, 2001; Grandia, 2001) suggests that the flow system would have involved at least the whole southern part of the Maestrat basin.

Understanding the main processes that control the distribution and properties of dolomitized geobodies is essential for the hydrocarbon industry. The Benicàssim outcrop analogue is an excellent example of faultcontrolled extensive stratabound dolomitization. The presented case study summarizes an attempt to quantify some of these processes in order to find general rules and improve the ability of prediction making. We have shown that, according to the calculations and conceptual model presented in this contribution, this type of extensive fault-controlled, stratabound hydrothermal dolomitization would only occur if huge fluid volumes are mobilized and transported, in a system driven by thermal convection. This process can take place when the geothermal gradient causes a high enough fluid density contrast between shallower and deeper fluids. Other examples of hydrothermal dolomitization caused by thermal convection are discussed in Morrow et al. (1988), Wilson et al. (1990), Spencer-Cervato and Mullis (1992), Coniglio et al. (1994), Wendte et al. (1998), Gasparrini et al. (2006) or Nader et al. (2012). The Benicàssim case study illustrates the strong interplay between fault zones, seals, basin configuration and fluid flow has a significant impact on the distribution of diagenetic/hydrothermal alterations and hence on reservoir quality.

\section{Conclusions}

This contribution presents an integrated approach to the principal constraints on the distribution of fault-controlled stratabound hydrothermal dolomitization of the AptianAlbian limestone of the Benicàssim outcrop analogue. Isotopic data is used to infer fluid characteristics and methods to quantify reactivity of dolomitizing fluids as well as mass and volume balances are introduced. As a result, a dolomitization model for this case study is proposed. The analysis performed in this study led to the following conclusions:

1. $\delta^{18} \mathrm{O}$ and $\delta^{13} \mathrm{C}$ stable isotope data and isotope fractionation trajectories of fluid-rock interaction indicate that dolomite formed at a temperature between 80 to $110^{\circ} \mathrm{C}$ from a fluid that interacted with the regional limestone. $\delta^{18} \mathrm{O}$ becomes lighter with progressive replacement. Similarly, hydrothermal calcite veins and burial calcite cements were formed between 80 and $140^{\circ} \mathrm{C}$, with characteristic light $\delta^{18} \mathrm{O}$ values. Meteoric calcite cements and veins as well as calcitized dolomite are also identified and characterized by heavier $\delta^{18} \mathrm{O}$ and lighter $\delta^{13} \mathrm{C}$.

2. ${ }^{87} \mathrm{Sr} /{ }^{86} \mathrm{Sr}$ data combined with preexisting crush-leach analyses and radiogenic isotopes suggest that the Benicàssim dolomitization resulted from the circulation of brines that interacted with underlying Triassic and/or basement rocks. Thus, hightemperature fluids circulated along high permeability layers, in thermal disequilibrium with the surrounding rocks, after flowing through basement rocks and large-scale faults.

3. Several potential fluid sources with magnesium for the Benicàssim dolomitization are analyzed. Geologic constraints and geochemical data indicate that seawater (or evolved/concentrated seawater), basement brines (which could also be evolved seawater) or a mixture of both were the most likely dolomitizing fluids.

4. The evaluation of the reactivity of such fluids by means of geochemical 
simulations results in an optimum range of dolomitization temperatures 75 to $125^{\circ} \mathrm{C}$. Concentrated seawater is the fluid with the most dolomitizing capacity, requiring a minimum fluid/rock ratio of $\sim 50$ in order to completely dolomitize a volume of rock. The reactivity of the modelled fluids is not directly proportional to $\mathrm{Mg}$ concentration or salinity.

5. In order to account for the volume of dolostone geobodies at Benicàssim, fluid volumes on the order of $10^{11}$ $10^{12} \mathrm{~m}^{3}$ are necessary to provide the $5 \cdot 10^{13}$ moles of $\mathrm{Mg}$ required. Release of overpressured fluids below seals during the Late Cretaceous or Early Paleocene could only provide fluid volumes 3-4 orders of magnitude smaller than required. Similarly, release of fluids by heating could only provide fluid volumes 2-3 order of magnitude smaller. Neither of those sources is volumetrically sufficient to dolomitize the Benicàssim limestones. Therefore, a long-lasting thermal convection system during the Late Cretaceous post-rift stage is the most plausible fluid flow mechanism for this dolomitization, since a fluid volume of the same order of magnitude as the required fluid can be stored within the rocks of the Benicàssim half graben.

6. Dolomitization similar to that of Benicàssim could have developed in basins with similar histories of rifting and post-rifting stages. Such geologic history leads to the development of a heterogeneous crust which facilitates long-term deep fluid convection.

\section{Acknowledgements}

This work was financed and supported by the ExxonMobil Upstream Research Company, ExxonMobil Production Company and the ExxonMobil (FC) ${ }^{2}$ Alliance (Fundamental Controls on Flow in
Carbonates). The views expressed in this article by Sherry L. Stafford are her own and not necessarily those of ExxonMobil. We thank Susan Agar for her strong support, as well as for many discussions and valuable suggestions, and the rest of the (FC) ${ }^{2}$ alliance members for their insights into the subject. We gratefully acknowledge C. Taberner and F.F. Whitaker, whose constructive reviews greatly improved the manuscript.

\section{References}

Barnolas, A.,Chiron, J. C. 1996. Synthèse géologique et géophysique des Pyrénées. BRGM-ITGE. 729 pp.

Al-Helal, A., Whitaker, F.F., Xiao, Y., 2012. Reactive transport modeling of brine reflux: dolomitization, anhydrite precipitation, and porosity evolution. Journal of Sedimentary Research 82, 196-215.

Allan, J.R., Wiggins, W.D., 1993. Dolomite reservoirs: Geochemical techniques for evaluating origin and distribution. American Association of Petroleum Geologists, Continuing Education Course Notes, 36.

Anderson, G.M., Garven, G., 1987. Sulfate-sulfidecarbonate associations in Mississippi Valley-type lead-zinc deposits. Economic Geology 82, 482-488.

Ayora, C., Taberner, C., Saaltink, M.W., Carrera, J., 1998. The genesis of dedolomites: a discussion based on reactive transport modeling. Journal of Hydrology 209, 346-365.

Bons P.D., van Milligen .B.P., 2001. A new experiment to model self-organized critical transport and accumulation of melt and hydrocarbons from their source rocks. Geology 29, 919-922.

Bover-Arnal, T., Martín-Martín, J.D., Gomez-Rivas, E., Travé, A., Salas, R., Moreno-Bedmar, J.A., Tomás, S., 2009a. Transgressive-regressive sequence analysis of the Upper Aptian carbonate succession of the south-eastern part of the Maestrat Basin (Iberian Chain, Spain). Amorosi, A. (ed.). 27th IAS Meeting of Sedimentologists - Alghero (Italy), September 2023, 2009. Medimond International Proceedings, 123127.

Bover-Arnal, T., Salas, R., Moreno-Bedmar, J.A., Bitzer, K., 2009b. Sequence stratigraphy and architecture of a late Early-Middle Aptian carbonate platform succession from the western Maestrat Basin (Iberian Chain, Spain). Sedimentary Geology 219, 280-231.

Braithwaite, C.J.R., Rizzi, G., Darke, G., 2004. The geometry and petrogenesis of dolomite hydrocarbon reservoirs: introduction. Geological Society of London Special Publication 235, 1-6.

Budd, D.A., 2001. Permeability loss with depth in the Cenozoic carbonate platform of west-central Florida. AAPG Bulletin 85-7, 1253-1272.

Caja, M.A., Salas, R., Marfil, R., Permanyer, A., 2009. Paleothermal constraints from diagenetic minerals 
recording high temperature conditions in a rift basin (Maestrat Basin, Iberian Range). Journal of Geochemical Exploration 101, 18.

Carmichael, S.K., Ferry, J.M., McDonough, W.F., 2008. Formation of replacement dolomite in the Latemar carbonate buildup, dolomites, Northern Italy: part 1. Field relations, mineralogy, and geochemistry. American Journal of Science 308, 851-884.

Casas, A.M., Pérez, A., Tena, S., Barrier, L., Gapais, D., Nalpas, T., 2000. Syn-tectonic sedimentation and thrust-and-fold kinematics at the intra-mountain Montalbán Basin (northern Iberian Chain, Spain). Geodinamica Acta 1, 1-17.

Cathles, L.M., Smith, A.T., 1983. Thermal constraints on the formation of Mississippi valley-type lead-zinc deposits and their implications for episodic basin dewatering and deposit genesis. Economic Geology 78, 983-1002.

Chacko, T., Mayeda, T.K., Clayton, R.N., Goldsmith, J.R., 1991. Oxygen and carbon isotope fractionations between $\mathrm{CO} 2$ and calcite. Geochimica et Cosmochimica Acta 55, 2867-2882.

Coniglio, M., Sherlock, R., Williams-Jones, A.E., Middleton, K., Frape, S.K., 1994. Burial and hydrothermal diagenesis of Ordovician carbonates from the Michigan Basin, Ontario, Canada. In: Purser, B.H., Tucker, M.E., Zenger, D.H. (Eds.), Dolomites - A Volume in Honour of Dolomieu. International Association of Sedimentology Special Publication 21, pp. 231-254.

Corbella, M., Ayora, C., Cardellach, E., 2004. Hydrotehrmal mixing, carbonate dissolution and sulfide precipitation in Mississippi Valley-type deposits. Mineralium Deposita 39, 344-357.

Corbella, M., Ayora, C., Cardellach, E., Soler, A., 2006. Reactive transport modeling and hidrotermal karst genesis: The example of Rocabruna barite deposit (Eastern Pyrenees). Chemical Geology 233, 113125.

Corbella, M., Gomez-Rivas, E., Martín-Martín, J.D., Stafford, S.L., Teixell, A., Griera, A., Travé, A., Cardellach, E., Salas, R., 2014. Controls on dolomitization by means of reactive transport models applied to the Benicàssim case study (Maestrat basin, E Spain). Petroleum Geoscience, in press.

Davies, G.R., Smith, L.B.J., 2006. Structurally controlled hydrothermal dolomite reservoir facies: An overview. AAPG Bulletin 90, 1641-1690.

Dawans, J.M., Swart, P.K., 1988. Textural and geochemical alterations in Late Cenozoic Bahamian dolomites. Sedimentology 35, 385-403.

Ebner, M., Toussaint, R., Schmittbuhl, J., Koehn, D., Bons, P.D., 2010. Anisotropic scaling of tectonic stylolites: a fossilized signature of the stress field? Journal of Geophysical Research 115, B06403.

Escorcia, L., Gomez-Rivas, E., Daniele, L., Corbella, M., 2013. Dedolomitization and reservoir quality, insights from reactive transport modeling. Geofluids 13(2), 221-231.
Garcia, R., Moreno-Bedmar, J.A., Bover-Arnal, T., Company, M., Salas, R., Latil, J.L., Martín-Martín, J.D., Gomez-Rivas, E., Bulot, L.G., Delanoy, G., Martínez, R., Grauges, A., 2013. Lower Cretaceous (Hauterivian-Albian) ammonite biostratigraphy in the Maestrat Basin (E Spain). Journal of Iberian Geology, in press.

Garven, G., Ge, S., Person, M.A. and Sverjensky, D.A., 1993. Genesis of stratabound ore deposits in the midcontinent basins of North America. 1. The role of regional groundwater flow. American Journal of Science 295, 497-568.

Gradstein, F.M., Ogg, J.G., Smith, A.G., 2004. A Geologic Time Scale. Cambridge University Press, Cambridge.

Gasparrini, M.,Bechstädt, T., Boni, M., 2006. Massive hydrothermal dolomites in the southwestern Cantabrian Zone (Spain) and their relation to the Late Variscan evolution. Marine and Petroleum Geology 23, 543-568.

Gomez-Rivas, E., Stafford, S.L., Lee, A.G.K., Corbella, M., Martín-Martín, J.D., Teixell, A., 2010a. Flow patterns of dolomitizing solutions in a buried carbonate ramp - the Benicassim case study (Maestrat Basin, NE Spain). Paper SPE 39522, presented at the 72nd European Association of Geoscientists and Engineers Conference and Exhibition, Barcelona, 2954-2959.

Gomez-Rivas, E., Corbella, M., Martín-Martín, J.D., Teixell, A., Cardellach, E., 2010b. Reactivity of dolomitizing fluids and evaluation of Mg sources in the Benicassim area (Maestrat Basin, E Spain). Paper SPE 39497, presented at the 72nd European Association of Geoscientists and Engineers Conference and Exhibition, Barcelona, 2831-2835.

Gomez-Rivas, E., Warber, K., Kulzer, F., Bons, P.D., Koehn, D., Martín-Martín, J.D., 2012. Structural evolution of the Benicàssim area (Maestrat basin, NE Spain): insights from fracture and vein analysis. Geogaceta 51, 79-82.

Grandia, F., Asmerom, Y., Getty, S., Cardellach, E., Canals, À., 2000. U-Pb dating of MVT ore-stage calcite: Implications for fluid flow in a Mesozoic extensional basin from Iberian Peninsula. Journal of Geochemical Exploration 69-70, 377-380.

Grandia, F., 2001. Origen, evolució i edat dels fluids associats a les mineralitzacions de $\mathrm{Zn}-\mathrm{Pb}$ en carbonats cretàcics de la Conca del Maestrat (Castelló-Teruel). Unpublished $\mathrm{PhD}$ thesis, Universitat Autònoma de Barcelona, Spain.

Grandia, F., Cardellach, E., Canals, A., Banks, D.A., 2003. Geochemistry of the fluids related to epigenetic carbonate-hosted $\mathrm{Zn}-\mathrm{Pb}$ deposits in the Maestrat Basin, Eastern Spain: fluid inclusion and isotope (Cl, C, O, S, Sr) evidence. Economic Geology 98, 933-954.

Gregg, J.M. 2004. Basin fluid flow, base-metal sulphide mineralization and the development of dolomite petroleum reservoirs. In: Braithwaite, C.J.R., Rizzi, 
G. and Darke, G. (eds) The Geometry and Petrogenesis of Dolomite Hydrocarbon Reservoirs. Geological Society of London Special Publication 235, 157-175.

Gregg, J.M., Sibley, D.F., 1984. Epigenetic dolomitization and the origin of xenotopic dolomite texture. Journal of Sedimentary Petrology 54: 908931.

Guimerà, J., Mas, R., Alonso, A., 2004. Intraplate deformation in the NW Iberian Chain: Mesozoic extension and Tertiary contractional inversion. Journal of the Geological Society 161, 291-303.

Hardie, L.A., 1987. Dolomitization; a critical view of some current views. Journal of Sedimentary Petrology 57, 166-183.

Helgeson, H.C., Kirkham, D.H., 1974. Theoretical prediction of the thermodynamic behavior of electrolytes at high pressures and temperatures: II. Debye-Huckel parameters for activity coefficients and relative partial molal properties. American Journal of Sciences 274, 1199-1261.

Inskeep, W.P., Bloom, P.R., 1986. Kinetics of calcite precipitation in the presence of water-soluble organic ligands. Soil Science Society of America Journal 50, 1167-1172.

Jones, C.E., Jenkins, H.C., 2001. Seawater strontium isotopes, oceanic anoxic events, and seafloor hydrothermal activity in the Jurassic and Cretaceous. American Journal of Science 301, 112-149.

Kaczmarek, S.E., Sibley, D.F., 2007. A comparison of nanometer-scale growth and dissolution features on natural and synthetic dolomite crystals: implications for the origin of dolomite. Journal of Sedimentary Research 77, 424-432.

Kaczmarek, S.E., Sibley, D.F., 2011. On the evolution of dolomite stoichiometry and cation order during high-temperature synthesis experiments: An alternative model for the geochemical evolution of natural dolomites. Sedimentary Geology 240, 30-40.

Kaufman, J., 1994. Numerical models of fluid flow in carbonate platforms - implications for dolomitization. Journal of Sedimentary Research, Sect. A 64, 128-139.

Kharaka, Y.K., Thordsen, J.J., 1992. Stable Isotope geochemistry and origin of waters in sedimentary basins. In: N. Clauer and S. Chauduri (Editors), Isotopic Signatures and Sedimentary Records. Lecture Notes in Earth Sciences 43, pp. 411-466.

Koehn, D., Renard, F., Toussaint, R., Passchier, C.W., 2007. Growth of stylolite teeth pattern depending on normal stress and finite compaction. Earth and Planetary Science Letters 257, 582-595.

Koehn, D., Ebner, M., Renard, F., Toussaint, R., Passchier, C.W. 2012. Modelling of stylolite geometries and stress scaling. Earth and Planetary Science Letters 341, 104-113.

Kulzer, F., 2011. Stylolites in the southeast Maestrat basin, Spain. How can stylolites aid the analysis of diagenetic and tectonic events?. MSc thesis, University of Mainz, Germany, 67 pp.
Land, L.S., 1985. The origin of massive dolomite. Journal of Geological Education 33, 112-125.

Lide, D. R., 2010. CRC Handbook of Chemistry and Physics, 90th ed.; CRC Press: Boca Raton, FL, 1993.

Lohmann, K.C. 1988. Geochemical patterns of meteoric diagenetic systems and their application to paleokarst. In: Choquette, P.W., James, N.P. (Edd), Paleokarst. New York, Springer Verlag, pp. 58-80.

Lucia, F.J., 2004. Origin and petrophysics of dolostone pore space. Geological Society of London Special Publication 235, 141-155.

Machel, H.G., 2004. Concepts and models of dolomitization: a critical reappraisal. Geological Society of London Special Publication 235, 7-63.

Martín-Chivelet, J., Berástegui, X., Caus, E,. Puig, C., 2002. Cretaceous. In: W. Gibbons and T. Moreno (Editors). Geology of Spain, Geological Society of London.

Martín-Martín, J.D., 2004. Los minerales de la arcilla del Permo-Triásico de la Cordillera Ibérica oriental: Procedencia y evolucion diagenética. Unpublished $\mathrm{PhD}$ thesis, Universidad Jaume I de Castellón, Spain, 189 pp.

Martín-Martín, J.D., Tritlla, J., Cardellach, E., GómezGras, D., 2006. Tectonically driven fluid flow and associated low-grade metamorphism during the Alpine compression in the eastern Iberian Chain (Spain). Journal of Geochemical Exploration 89, 267-270.

Martín-Martín, J.D., Travé, A., Gomez-Rivas, E., Sizun, J.P., Salas, R., Gómez-Gras, D., Vergés, J., 2010. Fault-associated dolomites in the Benicàssim area, Maestrat Basin, E. Spain - Macro- to micro-scale fluid flow in carbonates. Society of Petroleum Engineers - 72nd European Association of Geoscientists and Engineers Conference and Exhibition 2010 - Incorporating SPE EUROPEC 2010 4, 2980-2984.

Martín-Martín, J.D., Gomez-Rivas, E., Travé, A., Salas, R., Vergés, J., 2012. Dolomías asociadas a fracturas en carbonatos aptienses de la zona de Benicàssim (cuenca del Maestrat, Castelló). Geogaceta 51, 1922.

Martín-Martín, J.D., Gomez-Rivas, E., Bover-Arnal, T., Travé, A., Salas, R., Moreno-Bedmar, J.A., Tomás, S., Corbella, M., Teixell, A., Vergès, J., Stafford, S.L., 2013. The Upper Aptian to Lower Albian synrift carbonate succession of the southern Maestrat Basin (Spain): Facies architecture and faultcontrolled stratabound dolostones. Cretaceous Research 41, 217-236.

McCrea, J.M., 1950. On the isotopic chemistry of carbonates and a paleotemperature scale. Journal of Chemical Physics 18, 849-853.

Meléndez, A., Meléndez, F., Portero, J., Ramírez, J., 1985. Stratigraphy, sedimentology and paleogeography of Upper Cretaceous evaporiticcarbonate platforms in the Central part of the Sierra 
Ibérica. In: 6th. European regional Meeting. Excursion Guidebook, Lleida, p. 187-193.

Montaron, B., 2008. Confronting carbonates. Oil Review Middle East 5, 132-135.

Moreno-Bedmar, J.A., Company, M., Barragán, R., Salas, R., Martín-Martín, J.D., Bover-Arnal, T., Gomez-Rivas, E., 2009. Precisiones, mediante ammonoideos, sobre la edad de la Fm. Benassal, Cuenca del Maestrat (Cadena Ibérica). In: Palmqvist, P., Pérez-Claros, J.A. (Eds.), Comunicaciones de las XXV Jornadas de la Sociedad Española de Paleontología, "Darwin, la Teoría de la Evolución y la Paleontología” y simposios de los proyectos PICG 493, 499 y 506, Libro de Resúmenes. Universidad de Málaga, Málaga, pp. 231-234.

Moreno-Bedmar, J.A., Company, R., Bover-Arnal, T., Salas, R., Delanoy, G., Maurrasse, F.J.-M.R., Graugés, A., Martínez, R., 2010. Lower Aptian ammonite biostratigraphy in the Maestrat Basin (Eastern Iberian Chain, Easter Spain). A Tethyan transgressive record enhanced by synrift subsidence. Geologica Acta 8 (3), 281-299.

Morrow, D.W., 1998. Regional subsurface dolomitization: models and constraints. Geoscience Canada 25, 57-70.

Nadal, J., 2001. Estudi de la dolomitització del Juràssic superior-Cretaci inferior de la Cadena Ibérica oriental y la Cadena Costanera Catalana: relació amb la segona etapa de rift mesozoica. Unpublished PhD thesis, Universitat de Barcelona, Spain.

Nader, F.H., López-Horgue, M.A., Shah, M.M., Dewit, J., Garcia, D., Swennen, R., Iriarte, E., Muchez, P., Caline, B., 2012. The Ranero hydrothermal dolomites (Albian, Karrantza Valley, Northwest Spain): Implications on conceptual dolomite models. Oil \& Gas Science and Technology 67 (1), 9-29.

Obis, J.A., Canerot, J., Torres, T., Martínez, J.U., Moreno, E., Martínez, C., Granados, L., Schroeder, R., Pan, T., Mansialla, H., 1973. Mapa Geológico de España 1:50.000, hoja $n^{\circ} 616$ (Villafamés). IGME, Madrid.

O'Neil, J.R., Clayton, R.N., Mayeda, T.K., 1969. Oxygen isotope fractionation in divalent metal carbonates. Journal of Chemical Physics 51, 55475558.

Ortí, F., Salvany, J.M., 1990. Formaciones evaporíticas de la Cuenca del Ebro y cadenas periféricas, y de la zona de Levante: nuevas aportaciones y guía de superficie. Enresa, Madrid. 309 pp.

Parkhurst, D.L., Appelo, C.A.J., 1999. User's guide to PHREEQC - A computer program for speciation, batch-reaction, one-dimensional transport, and inverse geochemical calculations. U.S.G.S. WaterResources Investigations Report 99-4259.

Permanyer, A., Salas, R, Bitzer, K., 2000. Thermal modelling and geochemical constraints in the Late Jurassic of the Southern Iberian Chain (NE Spain). In: L.A. Trindade, A.C. Macedo and S.M. Barbanti (Editors), New perspectives on organic geochemistry for the Third Millenium. Proceedings of the 7th Latin-American congress on organic geochemistry, Brasil, pp. 179-182.

Person, M., Raffensperger, J.P., Ge, S., Garven, G., 1996. Basin-scale hydrogeologic modeling. Reviews of Geophysics 34, 61-87.

Plummer, L.N., Wigley, T.M.L., Parkhurst, D.L., 1978. The kinetics of calcite dissolution in $\mathrm{CO} 2$-water systems at 5 degrees to 60 degrees $\mathrm{C}$ and 0.0 to 1.0 atm CO2. American Journal of Science 278, 179216.

Purser, B.H., Brown, A., Aissaoui, D.M., 1994. Nature, origin and evolution of porosity in dolomites. In: Purser, B.H., Tucker, M.E., Zenger, D.H. (Eds.), Dolomites-A Volume in Honour of Dolomieu, Vol. 21. International Association of Sedimentology Special Publication, pp. 283-308.

Reinhold, C., 1998. Multiple episodes of dolomitization and dolomite recrystallization during shallow burial in Upper Jurassic shelf carbonates: eastern Swabian Alb, southern Germany. Sedimentary Geology 121, 71-95.

Roca, E., Guimerà, J., 1992. The Neogene structure of the eastern Iberian margin: structural constraints on the crustal evolution of the Valencia trough (western Mediterranian). Tectonophysics 203, 203-218.

Roca, E., Guimerà, J., Salas, R., 1994. Mesozoic extensional tectonics in the southeast Iberian Chain. Geological Magazine 131, 155-168.

Rodríguez-López, J.P., Meléndez, N., Soria, A.R, Liesa, C.L., Van Loon, A.J., 2007. Lateral variability of ancient seismites related to differences in sedimentary facies (the synrift Escucha Formation, mid-Cretaceous, eastern Spain). Sedimentary Geology 201, 461-484.

Roure, F., Swennen, R., Schneider, F., Faure, J.L., Ferket, H., Guilhaumou, N., Osadetz, K., Robion, P., Vandeginste, V., 2005. Impact de la tectonique et de la migration naturelle des fluides sur l'évolution des réservoirs dans les chaînes plissées et leurs avantpays. Oil \& Gas Science and Technology, Rev. IFP 60 (1), 67-106.

Saaltink, M.W., Batlle, F., Ayora, C., Carrera, J., Olivella, S., 2004. RETRASO, a code for modelling reactive transport in saturated and unsaturated porous media. Geologica Acta 2-3, 235-251.

Salas, R., Guimerà, J., Mas, R., Martín-Closas, C., Meléndez, A., Alonso, A., 2001. Evolution of the Mesozoic Central Iberian Rift System and its Cenozoic inversion (Iberian Chain). In: W. Cavazza, A.H.F. Robertson and P.A. Ziegler (Editors), Peritethyan rift/wrench basins and passive margins. Peri-Tethyan Memoirs.

Salas, R., 1987. El Malm i el Cretaci inferior entre el Massís del Garraf i la Serra d'Espadà. Unpublished $\mathrm{PhD}$ thesis, Universitat de Barcelona, Spain.

Salas, R., Casas, A., 1993. Mesozoic extensional tectonics, stratigraphy and crustal evolution during the Alpine cycle of the eastern Iberian basin. Tectonophysics 228, 33-55. 
Salas, R., Guimerà, J., 1996. Ragos estructurales principales de la cuenca cretácica inferior del Maestrazgo (Cordillera Ibérica Oriental). Geogaceta 20, 1704-1706.

Salas, R., Martín-Closas, C., Delclòs, X., Guimerà, J., Caja, M.A., Mas, R., 2005a. Factores principales de control de la sedimentación y los cambios bióticos durante el tránsito Jurásico-Cretácico en la Cadena Ibérica. Geogaceta 38, 15-18.

Salas, R., Caja, M.A., Martín-Martín, J.D., Mas, R., Permanyer, A., 2005b. Mid-Late Cretaceous volcanism, metamorphism and the regional thermal event affecting the Northeastern Iberian basins (Spain). In: Arnaud-Vanneau, A., Arndt, N., Zghal, I. (Eds.), Géologie Alpine. Laboratoire de Géologie de l'Université I de Grenoble, Grenoble.

Schmoker, J.W., Halley, R.B., 1982. Carbonate porosity vs. depth: a predictable relation for South Florida. AAPG Bulletin 66, 2561-2570.

Schrijver, K., Williams-Jones, A.E., Bertrand, R., Chagnon, A., 1996. Genesis and controls of hydrothermal dolomitization in sandstones of the Appalachian thrust belt, Québec, Canada: Implications for associated galena-barite mineralization. Chemical Geology 192, 257-279.

Sclater, J.G., Christie, P.A.F., 1980. Continental stretching: an explanation of the post-midCretaceous subsidence of the central North Sea Basin. Journal of Geophysical Research 85, 37113739.

Secor, D.T., Pollard, D.D., 1975. On the stability of open hydraulic fractures in the Earth's crust. Geophysical Research Letters 2, 510-513.

Shanks, W.C., Bischoff, J.L., 1997. Ore transport and deposition in the Red Sea geothermal system; a geochemical model. Geochimica et Cosmochimica Acta 41, 1507-1519.

Shelton, K.L., Bauer, R.M., Gregg, J.M., 1992. Fluidinclusion studies of regionally extensive epigenetic dolomites, Bonneterre Dolomite (Cambrian), southeast Missouri: Evidence of multiple fluids during dolomitization and lead-zinc mineralization. Geological Society of America Bulletin 104, 675683.

Simon Gomez, J.L., 1986a. Analysis of a gradual change in stress regime (example from the eastern lberian Chain, Spain). Tectonophysics 124, 31-53.

Simón-Gómez, J.L., 1986b. Sobre las deformaciones del paleozoico del macizo del Desierto de las Palmas (Castellón). Estudios Geológicos 42, 407-414.

Sjöberg, E.L., 1976. A fundamental equation for calcite dissolution kinetics. Geochimica et Cosmochimica Acta 40, 441-447.

Spencer-Cervato, C., Mullis, J., 1992. Chemical study of tectonically controlled hydrothermal dolomitization: an example from the Lessini Mountains, Italy. Geologische Rundschau 81 (2), 347-370.

Staude, S., Bons, P.D., Markl, G., 2009. Hydrothermal vein formation by extension- driven dewatering of the middle crust: An example from SW Germany. Earth and Planetary Science Letters 286, 387-395.

Stumm, W., Morgan, J.J., 1981. Aquatic Chemistry - An Introduction Emphasizing Chemical Equilibria in Natural Waters. 2nd ed., Wiley, New York.

Tester, J.W., Cline, J.A., 1999. Hydrolysis and oxidation in subcritical ad supercritical water: connecting process engineering science to molecular interactions. Corrosion 55, 1088-1100.

Tomás. S., 2007. Sistemas arrecifales del Cretácico inferior de la Cuenca del Maestrat. Modelos deposicionales, paleontológicos y diagenéticos. Unpublished $\mathrm{PhD}$ thesis, Universitat de Barcelona, Spain.

Tomás, S., Comas Nebot, M., Salas, R., 2007. La plataforma carbonatada Aptiense superior de Benicàssim-Orpesa (Cuenca del Maestrat, Cadena Ibérica): modelo de depósito. Geogaceta 41, 235 238.

Tomás, S., Löser, H., Salas, R., 2008. Low-light and nutrient-rich coral assemblages in an Upper Aptian carbonate platform of the southern Maestrat Basin (Iberian Chain, eastern Spain). Cretaceous Research 29, 509-534.

Tritlla, J., 1994. Geología y Metalogénia de las Mineralizaciones de Ba-Hg de la Sierra de Espadàn (Provincia de Castellón). Boletín de la Sociedad Española de Mineralogía 17, 245-246.

Tritlla, J., Cardellach, E., 1997. Fluid inclusions in preore minerals from the carbonate-hosted mercury deposits in the Espadán Ranges (eastern Spain). Chemical Geology 137, 91-106.

Tritlla, J., Cardellach, E., Sharp, Z.D., 2001. Origin of vein hydrothermal carbonates in Triassic limestones of the Espadán Ranges (Iberian Chain, E Spain). Chemical Geology 172, 291-305.

Tritlla, J., Sole, J., 1999. A newly dated Cretaceous hydrothermal event in the Iberian Ranges, (Eastern Spain) and its significance within the Mesozoic thermal history in the Iberian Peninsula. Ore Geology Reviews 15, 243-259.

Wallmann, K., 2001. Controls on the Cretaceous and Cenozoic evolution of seawater composition, atmospheric CO2 and climate. Geochimica et Cosmochimica Acta 65, 3005-3025.

Warren, J., 2000. Dolomite: occurrence, evolution and economically important associations. Earth-Science Reviews 52, 1-81.

Weisheit, A., Bons, P.D., Elburg, M.A., 2013. Longlived crustal-scale fluid flow: the hydrothermal mega-breccia of Hidden Valley, Mt. Painter Inlier,South Australia. International Journal of Earth Sciences (Geolische Rundschau) 102, 1219-1236.

Wendte, J., Qing, H., Dravis, J.J., Moore, S.L.O., Stasiuk, L.D., Ward, G., 1998. High temperature saline (thermoflux) dolomitization of Devonian Swan Hills platform and bank carbonates, Wild River area, west-central Alberta. Bulletin of the Canadian Petroleum Geology 46 (2), 210-265. 
Whitaker, F.F., Smart, P.L., Jones, G.D., 2004. Dolomitization: from conceptual to numerical models. Geological Society of London Special Publication 235, 99-139.

Whitaker, F.F., Xiao, Y., 2010. Reactive transport modeling of early burial dolomitization of carbonate platforms by geothermal convection. AAPG Bulletin 94, 889-917.

White, D.E. 1957. Thermal waters of volcanic origin. Geological Society of America Bulletin 68, 16371658.

Wilson, E.N., Lawrence, A.H., Phillips, O.M., 1990. Dolomitization front geometry, fluid flow patterns, and the origin of massive dolomite: the Triassic Latemar buildup, northern Italy. American Journal of Science 290, 741-796.

Wilson, M.E.J. Evans, M.J., Oxtoby, N.H., Nas, D.S., Donnelly, T., Thirlwall, M., 2007. Reservoir quality, textural evolution, and origin of fault-associated dolomites. AAPG Bulletin 91 (9), 1247-1272.

Xiao, Y., Jones, G.D., Whitaker, F.F., Al-Helal, A.B., Stafford, S.L., Gomez-Rivas, E., Guidry, S., 2013. Fundamental approaches to dolomitisation and carbonate diagenesis in different hydrogeological systems and the impact on reservoir quality distribution. 6th International Petroleum Technology Conference, 16579-MS. doi: 10.2523/16579-MS.

Zenger, D.H., Dunham, J.B., Ethington, R.L., 1980. Concepts and models of dolomitization, 28. Special Publication - SEPM, 320 pp.

Zheng, Y.-F., Hoefs, J., 1993. Carbon and oxygen isotopic covariations in hydrothermal calcites. Mineralium Deposita 28, 79-89.

Zheng, Y.-F., 1999. Oxygen isotope fractionation in carbonate and sulfate minerals. Geochemical Journal 33, 109-126. 